\title{
The TRPM1 Channel Is Required for Development of the Rod ON Bipolar Cell-AII Amacrine Cell Pathway in the Retinal Circuit
}

\author{
Takashi Kozuka, ${ }^{1,2}$ Taro Chaya, ${ }^{1,2}$-Fuminobu Tamalu, ${ }^{3}$ Mariko Shimada, ${ }^{1,2}$-Kayo Fujimaki-Aoba, ${ }^{3}$

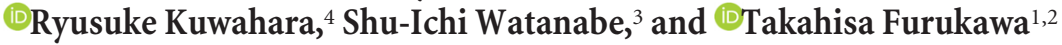 \\ ${ }^{1}$ Laboratory for Molecular and Developmental Biology, Institute for Protein Research, Osaka University, ${ }^{2}$ Japan Science and Technology Agency, Core \\ Research for Evolutional Science and Technology, Suita, Osaka 565-0871, Japan, ${ }^{3}$ Department of Physiology, Faculty of Medicine, Saitama Medical \\ University, Saitama 350-0495, Japan, and ${ }^{4}$ Research Center for Ultrahigh Voltage Electron Microscopy, Osaka University, Ibaraki, Osaka 567-0047, Japan
}

Neurotransmission plays an essential role in neural circuit formation in the central nervous system (CNS). Although neurotransmission has been recently clarified as a key modulator of retinal circuit development, the roles of individual synaptic transmissions are not yet fully understood. In the current study, we investigated the role of neurotransmission from photoreceptor cells to ON bipolar cells in development using mutant mouse lines of both sexes in which this transmission is abrogated. We found that deletion of the ON bipolar cation channel TRPM1 results in the abnormal contraction of rod bipolar terminals and a decreased number of their synaptic connections with amacrine cells. In contrast, these histological alterations were not caused by a disruption of total glutamate transmission due to loss of the ON bipolar glutamate receptor mGluR6 or the photoreceptor glutamate transporter VGluT1. In addition, TRPM1 deficiency led to the reduction of total dendritic length, branch numbers, and cell body size in AII amacrine cells. Activated Go $\alpha$, known to close the TRPM1 channel, interacted with TRPM1 and induced the contraction of rod bipolar terminals. Furthermore, overexpression of Channelrhodopsin-2 partially rescued rod bipolar cell development in the TRPM1 ${ }^{-1-}$ retina, whereas the rescue effect by a constitutively closed form of TRPM1 was lower than that by the native form. Our results suggest that TRPM1 channel opening is essential for rod bipolar pathway establishment in development.

Key words: cation channel; neurotransmission; retina; retinal circuit formation

Significance Statement

Neurotransmission has been recognized recently as a key modulator of retinal circuit development in the CNS. However, the roles of individual synaptic transmissions are not yet fully understood. In the current study, we focused on neurotransmission between rod photoreceptor cells and rod bipolar cells in the retina. We used genetically modified mouse models which abrogate each step of neurotransmission: presynaptic glutamate release, postsynaptic glutamate reception, or transduction channel function. We found that the TRPM1 transduction channel is required for the development of rod bipolar cells and their synaptic formation with subsequent neurons, independently of glutamate transmission. This study advances our understanding of neurotransmissionmediated retinal circuit refinement.

\section{Introduction}

A landmark study by Hubel and Wiesel (1962) showing that visual deprivation affects the visual system development pioneered

Received March 26, 2017; revised Sept. 1, 2017; accepted Sept. 6, 2017.

Author contributions: T.K., T.C., and T.F. designed research; T.K., F.T., M.S., K.F.-A., R.K., and S.-I.W. performed research; T.K., F.T., M.S., K.F.-A., and S.I.W. analyzed data; T.K., T.C., F.T., and T.F. wrote the paper.

This work was supported by Grant-in-Aid for Scientific Research (B; 15H04669), Grant-in-Aid for Scientific Research (C; 16K08504), Young Scientists (B; 17K15548) from Japan Society for the Promotion of Science, Nanotechnology Platform (12024046) from The Ministry of Education, Culture, Sports, Science and Technology, The Takeda Science Foundation, Senri Life Science Foundation, KANAE Foundation for the Promotion of Medical Science, and Terumo Foundation for Life Science and Arts Life Science support program; and performed in part under the Cooperative Research Program of the Institute for Protein Research, Osaka University, CRa-17-03. We thank investigation into the importance of synaptic transmission to the development of neural circuits in the CNS. In neural circuits of

Dr. S. Nakanishi (Osaka Bioscience Institute) for the $m G l u R 6^{-/-}$mouse; Dr. S. Takamori (Doshisha University) for the VGluT1 $1^{-/-}$mouse; Drs. Y. Omori and R. Sanuki for expertise; M. Kadowaki, A. Tani, A. Ishimaru, Y. Tojima, K. Tsujii, H. Abe, and S. Kennedy for technical assistance.

The authors declare no competing financial interests.

Correspondence should be addressed to Takahisa Furukawa, Laboratory for Molecular and Developmental Biology, Institute for Protein Research, Osaka University, 3-2 Yamadaoka, Suita, Osaka, 565-0871, Japan. E-mail: takahisa.furukawa@protein.osaka-u.ac.jp.

M. Shimada's present address: Environmental Health Science Laboratory, Sumitomo Chemical Co., Ltd, 3-1-98 Kasugadenaka Konohanaku, 0saka, 554-8558, Japan.

DOI:10.1523/JNEUROSCI.0824-17.2017

Copyright $\odot 2017$ the authors $\quad 0270-6474 / 17 / 379889-12 \$ 15.00 / 0$ 
the brain, synaptic formation and disruption, as well as neural process outgrowth and retraction, occur continuously. It has been demonstrated that these phenomena are also necessary for neural circuit formation and are mediated by neurotransmission during brain development (Hua and Smith, 2004). In the retina, the importance of synaptic transmission for retinal circuit formation was revealed by the observation that light deprivation altered the stratification of retinal ganglion cell (RGC) dendrites (Tian and Copenhagen, 2003; Xu and Tian, 2007) and reduced the number of synaptic connections between cone photoreceptors and cone bipolar cells in some types of cone bipolar cells (Dunn et al., 2013). Furthermore, analyses using genetically modified animals, in which specific synaptic transmissions are inhibited, have gradually clarified the roles of individual synaptic transmissions. Inhibition of synaptic transmission from ON bipolar cells to RGCs reduces the number of synapse connections with the ON RGCs (Kerschensteiner et al., 2009; Okawa et al., 2014). Inhibition of inhibitory synaptic transmission throughout the retina influences the morphology of ON and OFF bipolar cells in a cell-type-specific manner (Hoon et al., 2015). It was previously reported that 2-amino-4-phosphonobutyric acid (APB), which blocks the light response of ON bipolar cells through metabotropic glutamate receptor 6 (mGluR6) activation, disrupted the normal course of dendritic stratification in developing retinal ganglion cells (Bodnarenko and Chalupa, 1993) and that lightdependent morphological changes of rod bipolar cell axons are inhibited by mGluR6 deletion (Ishii et al., 2009). However, the role of synaptic transmission of photoreceptors in bipolar cell development and the underlying mechanism are not fully understood.

In the mammalian retina, visual information received by photoreceptors is segregated into ON and OFF pathways that are mediated by ON and OFF bipolar cells, respectively. ON bipolar cells, which depolarize under light stimulation, develop axons that terminate in the inner half of the inner plexiform layer (IPL), sublamina $b$. In contrast, OFF bipolar cells hyperpolarize under light stimulation and extend axons that terminate in the outer half of the IPL, sublamina $a$ (Ghosh et al., 2004). Bipolar cells can also be divided into two major groups, depending on whether they connect to rods or cones. Cone bipolar cells, including ON and OFF types, receive signal inputs from cone photoreceptors and directly connect to RGC dendrites in the IPL. In contrast, rod bipolar cells are only ON bipolar cells and their axonal terminals extend to the deepest region of the IPL. Rod bipolar cells rarely contact RGCs directly, rather they functionally connect to RGCs through AII and A17 amacrine cells (Kolb and Famiglietti, 1974; Freed et al., 1987).

We previously reported that transient receptor potential M1 (TRPM1) is a cation channel expressed in ON bipolar cells that mediates neurotransmission between photoreceptors and $\mathrm{ON}$ bipolar cells (Koike et al., 2010b). Their neurotransmission mechanism is as follows: when photoreceptors are depolarized, glutamates packed in synaptic vesicles via vesicular glutamate transporter 1 (VGluT1) are released from photoreceptor terminals. The released glutamates are received by mGluR6, which is localized at the dendritic tips of ON bipolar cells. G-proteins activated by mGluR6 close the TRPM1 channel (Koike et al., 2010a,b; Shen et al., 2012; Xu et al., 2016). In the current study, to reveal the role of synaptic transmission from photoreceptors to ON bipolar cells in rod bipolar cell development, we analyzed TRPM1, mGluR6, and VGluT1 mutant mouse retinas.

\section{Materials and Methods}

Animal care. All procedures conformed to the Association for Research in Vision and Ophthalmology statement for the Use of Animals in Ophthalmic and Vision Research, and Guiding Principles for the Care and Use of Animals in the Field of Physiological Sciences, The Physiological Society of Japan, and these procedures were approved by the Institutional Safety Committee on Recombinant DNA Experiments (approval ID 4220), Animal Experimental Committees of the Institute for Protein Research (approval ID 29-01-0), Osaka University, and the Animal Research Committee of Saitama Medical University, and were performed in compliance with institutional guidelines. Mice were housed in a temperaturecontrolled room at $22^{\circ} \mathrm{C}$ with a $12 \mathrm{~h} \mathrm{light/dark} \mathrm{cycle.} \mathrm{Fresh} \mathrm{water} \mathrm{and}$ rodent diet were available at all times.

Plasmid constructs. Full-length cDNA fragments of mouse TRPM1 and $m$ GluR6 were amplified by PCR using mouse retinal cDNA, then subcloned into the pCAGGS-C-3xFlag vector. Full-length cDNA fragments of mouse Go $\alpha$ and Go $\alpha$ (Q205L) were amplified by PCR using previously constructed plasmids (Koike et al., 2010b) as a template, then subcloned into the pCAGGS-N-2xHA vector. Primer sequences are as follows: for full-length TRPM1, forward, 5' -CTTATCGATGCCACCATGGGGTCC ATGAGGAAGATGAGCAGC-3' and reverse, 5'-CTTGCGGCCGCTG CACTCAGTTTCCGCGCTTCTTTTCTC-3'; full-length Grm6, forward, 5'-CTTCTCGAGGCCACCATGGGGCGGCTCCGAGTGCTGCTGC TG-3' and reverse, 5' $^{\prime}$-CTTGCGGCCGCACTTGGCGTCCTCTGAGTT CTCGCTCTTG-3'; full-length Go $\alpha$ and $G o \alpha(Q 205 L)$, forward, 5' -CTT GAATTCGATGGGATGTACGCTGAGCGCAGA- $3^{\prime}$ and reverse, $5^{\prime}$-AA GCTCGAGTCAGTACAAGCCGCAGCCCCGGA-3'. Full-length cDNA fragments of mouse $G o \alpha(Q 205 L)$ were also ligated into the pCAGGSIRES-GFP (pCIG) vector (Matsuda and Cepko, 2004) digested with EcoRI and NotI. To obtain the Grm6 enhancer element, which is well conserved between mouse and human genomes (see Fig. 6A) and overlapping, but slightly shifted, from the previously reported Grm6 enhancer (Lagali et al., 2008), we amplified the element from the mouse genome using the primers $5^{\prime}$-TCCATGGTGCTTTCTGTAGGCTTTTAG TTAATAG-3' and 5' -TGCTAGCGAGATGTACTTTAGCAGATTAACG ATTTGG-3' and then subcloned into the pGL3-Basic vector (Promega) and fused to a SV40 eukaryotic promoter. EGFP digested from the pEGFP-Basic vector was inserted downstream of the Grm6 enhancerSV40 promoter, generating the pGrm6-EGFP plasmid. ChR2(C128S) was generated by site-directed mutagenesis using the pACAGW-ChR2Venus-AAV vector (Addgene, plasmid 20071) as a template. The primer sequences are 5' -ACCTCTCCGGTCATTCTCATTCACCTG-3' and 5'GAGAAGCCACTCGGCGTAA CGCAACCA-3'. ChR2(C128S)-Venus digested from the pACAGW-ChR2(C128S)-Venus-AAV vector was inserted downstream of the Grm6 enhancer-SV40 promoter, generating the pGrm6-ChR2(C128S)-Venus plasmid. Grm6 enhancer-SV40 promoter was ligated into the pCIG vector digested with KpnI and HindIII, generating the pGrm6-IRES-EGFP plasmid. A1068T mutation in TRPM1 was introduced by site-directed mutagenesis. TRPM1 or TRPM1(A1068T) was ligated into the pGrm6-IRES-EGFP vector digested with PmeI and NotI, generating the pGrm6-TRPM1-IRES-EGFP or pGrm6-TRPM1 (A1068T)-IRES-EGFP.

Immunohistochemistry. Immunohistochemical analysis of retinal sections was performed as described previously (Sanuki et al., 2015). Mouse eyecups were fixed with $4 \%$ paraformaldehyde in PBS for $30 \mathrm{~min}$ or $2 \mathrm{~h}$. The tissues were then rinsed in PBS, cryoprotected with 30\% sucrose in PBS, embedded in Tissue-Tek OCT compound 4583 (Sakura), frozen, and sectioned. For immunohistochemistry, frozen $16 \mu \mathrm{m}$ sections on slides were dried for $30 \mathrm{~min}$ at room temperature, rehydrated in PBS for 5 min, permeabilized with $0.1 \%$ Triton X-100 (w/v) in PBS, and then incubated in $4 \%$ normal donkey serum and $0.02 \%$ Triton X-100 in PBS for blocking. The samples were then incubated with primary antibodies at $4^{\circ} \mathrm{C}$ overnight. Slides were washed with PBS three times for $10 \mathrm{~min}$ each time and incubated with secondary antibodies for $2 \mathrm{~h}$ at room temperature. Flat-mount immunostaining of the retina was performed as described previously (Irie et al., 2015). Each retina was gently peeled off from the sclera, rinsed in PBS, and fixed with $4 \%$ paraformaldehyde in PBS for 30 min. After washing in PBS, samples were blocked with $4 \%$ 
normal donkey serum and $0.5 \%$ Triton X-100 (w/v) in PBS for $2 \mathrm{~h}$. The retinas were then immunostained with primary antibodies for two overnights at $4^{\circ} \mathrm{C}$. Reactions with secondary antibodies were performed for two overnights at $4^{\circ} \mathrm{C}$. Hoechst (Sigma-Aldrich) was used for nuclear staining. The specimens were observed under a laser confocal microscope (LSM700, Carl Zeiss). Primary antibodies used in this study are described as follows: anti-Calbindin (Sigma-Aldrich, PC253L; rabbit, 1:1000), anti-GFP (Nacalai, 04404-26; rat, 1:1000), anti-Calsenilin (Millipore, 05-756; mouse, 1:100), anti-PKC $\alpha$ (Sigma-Aldrich, P4334; rabbit, 1:10,000), anti-PKC $\alpha$ (Millipore, 05-154; mouse, 1:100), antiCtBP2 (BD Biosciences, 612044; mouse, 1:200), anti-PSD95 (Thermo Scientific, MA1-046; mouse, 1:300), anti-Dab1 (Millipore, AB5840; rabbit, 1:100), and anti-Znp1 (ZIRC, ZDB-ATB-081002-25; mouse, 1:500) antibodies. We used Cy3-conjugated (Jackson ImmunoResearch Laboratories; 1:500) and AlexaFluor 488-conjugated (Sigma-Aldrich; 1:500) secondary antibodies.

Immunoprecipitation assay. HEK293T cells were cotransfected with the pCAGGS-3xFLAG-TRPM1 or pCAGGS-3xFLAG-mGluR6 expression plasmids together with the pCAGGS-2xHA-Go $\alpha$ or pCAGGS2xHA-Go $\alpha(\mathrm{Q} 205 \mathrm{~L})$ expression plasmids. Two days after transfection, the cells were lysed in PBS containing 1\% Triton X-100 and Complete Protease Inhibitor Cocktail (Roche), and centrifuged for $10 \mathrm{~min}$ at $15,100 \times g$. The supernatants were incubated with an anti-FLAG M2 affinity gel (Sigma-Aldrich) or a monoclonal anti-HA-agarose antibody (Sigma-Aldrich) and then eluted with $0.1 \mathrm{~m}$ glycine buffer, $\mathrm{pH} 1.5$. After neutralization with $1 \mathrm{~m}$ Tris- $\mathrm{HCl}, \mathrm{pH} 9.0$, immunoprecipitated samples were analyzed by Western blotting.

Western blot analysis. Western blot analysis was performed as described previously (Chaya et al., 2014). Samples were separated by SDSPAGE and transferred to PVDF membranes. We used the following primary antibodies: anti-Flag (Sigma-Aldrich, F1804; mouse, 1:10,000) and anti-HA (Roche, 11-867-423-00; rat, 1:5000) antibodies. After washing with TBS/ $0.1 \%$ Tween 20 , the membrane was then incubated with a horseradish peroxidase-conjugated donkey anti-mouse $\operatorname{IgG}(1: 10,000$; Jackson ImmunoResearch) or donkey anti-rat IgG (1:10,000; Jackson ImmunoResearch). The bands were visually developed using ChemiLumi One L (Nacalai).

In vivo electroporation. In vivo electroporation was performed on the postnatal day $0(\mathrm{P} 0)$ mouse retina as described previously (Watanabe et al., 2015). Plasmids in $0.3 \mu \mathrm{l}$ of PBS at a concentration of $5 \mu \mathrm{g} / \mu \mathrm{l}$ were injected into P0 mouse retinas followed by in vivo electroporation. The electroporated retinas were harvested at 1 month old (1M), spread flat, and immunostained with antibodies against GFP and PKC $\alpha$. Images were obtained using a confocal microscope LSM700 (Zeiss), and the areas of both EGFP- and PKC $\alpha$-positive axon terminals of rod bipolar cells were measured using the MetaMorph software (Molecular Devices).

Transmission electron microscope. Transmission electron microscope analysis was performed as described previously with some modifications (Omori et al., 2015). Eye cups were fixed with 2\% glutaraldehyde, $2 \%$ paraformaldehyde in $0.1 \mathrm{~m}$ phosphate buffer. After fixation with $1 \%$ osmium tetraoxide for $3 \mathrm{~h}$, the retinas were dehydrated through a graded series of ethanol $(30-100 \%)$ and propylene oxide. Finally, the retinas were embedded in epoxy resin. Sections were cut on an ultramicrotome (EM UC7, Leica) and stained with uranyl acetate and lead citrate. Retinal sections were observed by transmission electron microscope (H-7500, Hitachi).

Slice preparation. Mice of either sex at $1 \mathrm{M}$ were dark-adapted for $>3 \mathrm{~h}$ before the experiment to make it easy to isolate the retina from the pigmented epithelium. Under light conditions, the retina was isolated in an external solution containing the following (in $\mathrm{mm}$ ): $120 \mathrm{NaCl}, 3 \mathrm{KCl}$, $2.5 \mathrm{CaCl}_{2}, 1 \mathrm{MgCl}_{2}, 10$ glucose, and $25 \mathrm{NaHCO}_{3}$ equilibrated with $95 \%$ $\mathrm{O}_{2} / 5 \% \mathrm{CO}_{2}, \mathrm{pH} 7.4$, and then placed on a piece of mixed cellulose ester filter paper $(0.2 \mu \mathrm{m}$ pore size; ADVANTEC) with the photoreceptor side up. To firmly attach each retina to the filter paper, suction was applied from the back of the filter paper. Retinal slices, $200 \mu \mathrm{m}$ thick, were cut vertically with a custom-made tissue chopper and fixed to the glass bottom of the recording chamber ( $1.5 \mathrm{ml}$ in volume) with a small amount of silicone grease (Dow Corning). All experiments were performed under room temperature. The chamber was continuously perfused $(1.5 \mathrm{ml} / \mathrm{min})$ with external solution.

Patch-clamp recording from retinal slices. Whole-cell patch-clamp recordings were made from AII amacrine cells in the central retina, within $\approx 2 \mathrm{~mm}$ eccentricity. Recordings were performed with an Axopatch $200 \mathrm{~B}$ amplifier (Molecular Devices), using pCLAMP 9.2 software (Molecular Devices). The retinal slice preparations were visualized using an upright microscope (BX50WI, Olympus) equipped with DIC optics and a $60 \times$ water-immersion objective. The patch pipettes (7-9 M $\Omega$ ) were filled with an internal solution containing the following (in $\mathrm{mM}$ ): 120 K-gluconate, $6 \mathrm{KCl}, 2 \mathrm{NaCl}, 1 \mathrm{CaCl}_{2}, 1 \mathrm{MgCl}_{2}, 5 \mathrm{EGTA}, 10$ HEPES, 4 $\mathrm{Na}_{2} \mathrm{ATP}$, and $0.5 \mathrm{GTP}, \mathrm{pH} 7.2$, for measuring membrane capacitances, or (in mM) $123 \mathrm{~K}$-gluconate, $6 \mathrm{KCl}, 10 \mathrm{NaCl}, 1 \mathrm{CaCl}_{2}, 1 \mathrm{MgCl}_{2}, 2 \mathrm{EGTA}$, and 10 HEPES, pH 7.2, for capturing confocal images. 0.1\% Lucifer yellow $\mathrm{CH}$ dilithium salt was added to the internal solutions to visualize the morphology of the cells. $Z$-stack images of Lucifer yellow-filled cells in an external solution containing the following (in $\mathrm{mM}$ ): $135 \mathrm{NaCl}, 3$ $\mathrm{KCl}, 2.5 \mathrm{CaCl}_{2}, 1 \mathrm{MgCl}_{2}, 10$ glucose, and 10 HEPES, $\mathrm{pH}$ 7.4, were captured using a laser confocal microscope (LSM710, Carl Zeiss). Total dendritic length and branch numbers were calculated using the MetaMorph Neurite Outgrowth Module. Membrane capacitance was measured by reading the value for slow capacitance after optimal compensation of capacitance currents in whole-cell configuration.

Identification of AII amacrine cells in retinal slices. We confirmed the identity of AII amacrine cells using the following morphological criteria revealed by Lucifer yellow injection and electrophysiological features: (1) location of the cell body at the border between the inner nuclear layer (INL) and the IPL but protruding slightly into the IPL; (2) the size of the cell body ( $\approx 8 \mu \mathrm{m}$ in diameter); (3) a thick primary dendrite descending into sublamina $a$ of the IPL, where it gives rise to large synaptic endings termed lobular appendages and terminates with a densely branched dendritic plexus termed the arboreal dendrite in sublamina $b$ (Kolb and Famiglietti, 1974; Strettoi et al., 1992; Wässle et al., 1995); (4) electrophysiological "signature" of an AII amacrine cell whereby depolarization steps form a holding potential of $-60 \mathrm{mV}$ and evoke action currents escaping from voltage-clamp, recorded after establishment of whole-cell configuration (Mørkve et al., 2002; Veruki and Hartveit, 2002b); and (5) repetitive action potentials of small amplitude $(5 \sim 15 \mathrm{mV})$ evoked by depolarization from a membrane potential of $-60 \sim 70 \mathrm{mV}$ in currentclamp mode (Veruki et al., 2003; Tamalu and Watanabe, 2007; Cembrowski et al., 2012).

Experimental design and statistical analysis. All animal experiments were performed on mice of both sexes. All statistical analyses were performed using GraphPad Prism v6.04 (GraphPad Software). Single comparisons were performed using two-tailed unpaired Student's $t$ test, and multiple comparisons were performed using one-way ANOVA with post hoc Tukey-Kramer test. All values are presented as mean $\pm \mathrm{SD}$. The analyzed number of samples is indicated in the figure legends.

Measurement of CtBP2 puncta in rod bipolar cell axon terminals (see Fig. 2E): one-way ANOVA with post hoc Tukey-Kramer test was used. Analysis of electrophysiological and morphological characteristics of AII amacrine cells (see Fig. $3 A, C, D, F$ ): one-way ANOVA with post hoc Tukey-Kramer test was performed. Measurement of axon terminal areas of rod bipolar cells (see Figs. 5G, I,J, 6E,H): unpaired Student's $t$ test was used.

\section{Results \\ TRPM1 is required for axon terminal formation in rod bipolar cells}

To investigate whether lack of visual transduction influences rod bipolar cell development, we examined TRPM1, mGluR6, and VGluT1 mutant mice, all of which have signal transduction between photoreceptors and ON bipolar cells blocked (Fig. 1). In the $V G l u T 1^{-1-}$ retina, glutamate release from photoreceptors is inhibited (Johnson et al., 2007). In the $m G l u R 6^{-1-}$ retina, ON bipolar cells do not receive glutamates released from photoreceptors (Nomura et al., 1994). In the TRPM1 ${ }^{-1-}$ retina, cation influx into ON bipolar cells is abrogated (Koike et al., 2010b). It was 

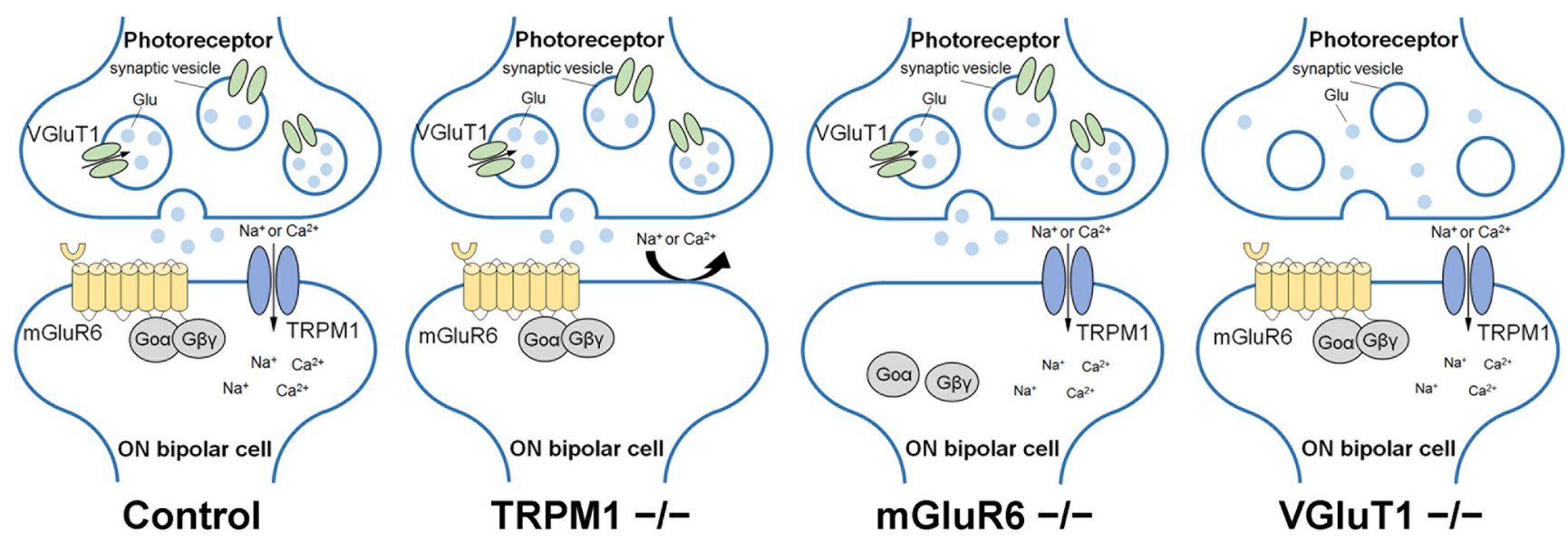

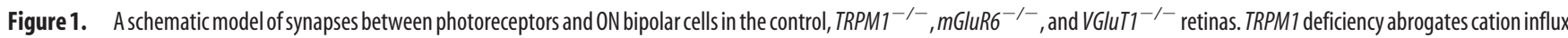

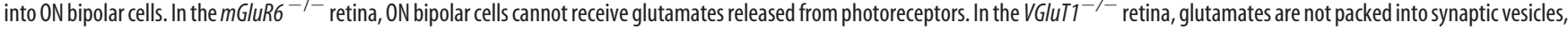
resulting in an inhibition of glutamate release from photoreceptors. Glu, Glutamate.

previously reported that these mutant mice exhibit a no b-wave phenotype, displaying no significant ERG b-wave, and that rod bipolar cell responses to light stimulation were completely undetectable in the TRPM1 $1^{-1-}$ and $m G l u R 6^{-1-}$ retinas (Koike et al., 2010b; Xu et al., 2012). We immunostained PKC $\alpha$ (a rod bipolar cell marker) in retinal sections of $1 \mathrm{M}$ mutant mice to observe the morphologies of rod bipolar cells. In the TRPM1 $1^{-/-}$retina, but not in the $m G l u R 6^{-1-}$ and VGluT1 $1^{-1-}$ retinas, PKC $\alpha$ signals were markedly reduced in the IPL (Fig. 2A). To observe the axon terminals of rod bipolar cells in more detail, we performed flatmount immunostaining of PKC $\alpha$ and CtBP2 (a synaptic ribbon marker; Fig. 2B-D). Axon terminal morphologies of rod bipolar cells in the TRPM1 $1^{-1-}$ retina were markedly smaller compared with those in the control, $m G l u R 6^{-1-}$, and VGluT1 ${ }^{-1-}$ retinas. Although the no b-wave phenotype is common to all mutant mice examined, the structural alterations of rod bipolar cell axon terminals were observed only in the TRPM1 ${ }^{-1-}$ retina. These results suggest that the TRPM1 channel is necessary for proper development of rod bipolar cell axon terminals, although glutamate transmission between photoreceptors and rod bipolar cells is not required for that. We then measured the number of CtBP2 signals contained in an axon terminal of a rod bipolar cell as an indicator of the synaptic connection between rod bipolar cells and amacrine cells, because the number of synaptic ribbons in axon terminals of rod bipolar cells can be determined by counting the number of CtBP2-positive puncta in the terminals of rod bipolar cells identified by PKC $\alpha$ labeling (Wan et al., 2010). Consistent with the observation of rod bipolar axon terminals, the number of CtBP2-positive puncta significantly decreased in the TRPM $1^{-1-}$ retina compared with that in the control, $m G l u R 6^{-1-}$, and VGluT1 ${ }^{-1-}$ retinas (Fig. $2 E ; F_{(3,41)}=55.46, p<0.0001$, ANOVA). These results suggest that the number of synaptic connections between rod bipolar cells and amacrine cells decrease in the TRPM1 ${ }^{-1-}$ retina. To observe whether rod bipolar cells correctly formed ribbon synapses, which contain two amacrine cell dendrites and a synaptic ribbon in a rod bipolar cell, in the IPL, we performed a conventional electron microscopy analysis (Fig. $2 F$ ). We observed two amacrine cell dendrites in close proximity to the axon terminal of a rod bipolar cell and a synaptic ribbon contained in the axon terminal in all examined mouse lines.
AII amacrine cell development is impaired in $T R P M 1^{-/-}$and VGluT1 ${ }^{-/-}$retinas

To investigate whether loss of TRPM1 influences the output neurons of rod bipolar cells, we examined the morphology and electrophysiological characteristic of AII amacrine cells in the $T_{R P M 1}{ }^{-1-}$ retina. The AII amacrine cell is a key hub for information flow, linking rod- and cone-driven retinal circuits (Demb and Singer, 2012). Although AII amacrine cells provide sustained inhibition to some RGCs under daylight conditions (Manookin et al., 2008), they are principally known for transferring roddriven signals into the cone network as a part of the rod pathway (Bloomfield and Dacheux, 2001). The axon terminals of rod bipolar cells mainly interact with AII amacrine cells in sublamina $b$ of the IPL. The AII amacrine cells form sign-inverting synaptic interactions with axonal processes of OFF cone bipolar cells in sublamina $a$ of the IPL and sign-preserving gap junctions with axonal processes of ON cone bipolar cells in sublamina $b$ (Strettoi et al., 1992, 1994; Veruki and Hartveit, 2002a). To examine the electrophysiological characteristic of AII amacrine cells, we measured membrane capacitance of AII amacrine cells in retinal slices at $1 \mathrm{M}$ (Fig. 3A). Membrane capacitance significantly decreased in the TRPM1 ${ }^{-1-}$ retina compared with that in the control and $m G l u R 6^{-l-}$ retinas (Fig. $3 A ; F_{(3,44)}=13.37, p<0.0001$, ANOVA). We also observed a decrease of membrane capacitance in the $V G l u T 1^{-1-}$ retina. It is known that membrane capacitance correlates with the surface area of the cell membrane (Neher and Marty, 1982). To observe AII amacrine cell dendrites, we injected Lucifer yellow into AII amacrine cells and measured their total dendritic length and branch numbers (Fig. $3 B$ ). As expected, total dendritic length and branch numbers of AII amacrine cells in the TRPM1 $1^{-1-}$ and VGluT1 $1^{-1-}$ retinas significantly decreased (Fig. $3 C$ and $D ; F_{(3,35)}=11.25, p<0.0001$, ANOVA, and $F_{(3,35)}=$ 10.49, $p<0.0001$, ANOVA, respectively). To analyze the cell body morphologies of AII amacrine cells, we performed flatmount immunostaining for Dab1 (an AII amacrine cell marker; Fig. $3 E$ ). We found that cell body sizes of AII amacrine cells in the $T_{R P M 1}{ }^{-1-}$ and $V G l u T 1^{-1-}$ retinas are significantly smaller compared with those in the control and $m G l u R 6^{-1-}$ retinas (Fig. $3 F ; F_{(3,92)}=15.60, p<0.0001$, ANOVA). Because it is known that VGluT1 is not only expressed in photoreceptors, but also in bipolar cells (Johnson et al., 2003), alterations of AII amacrine 

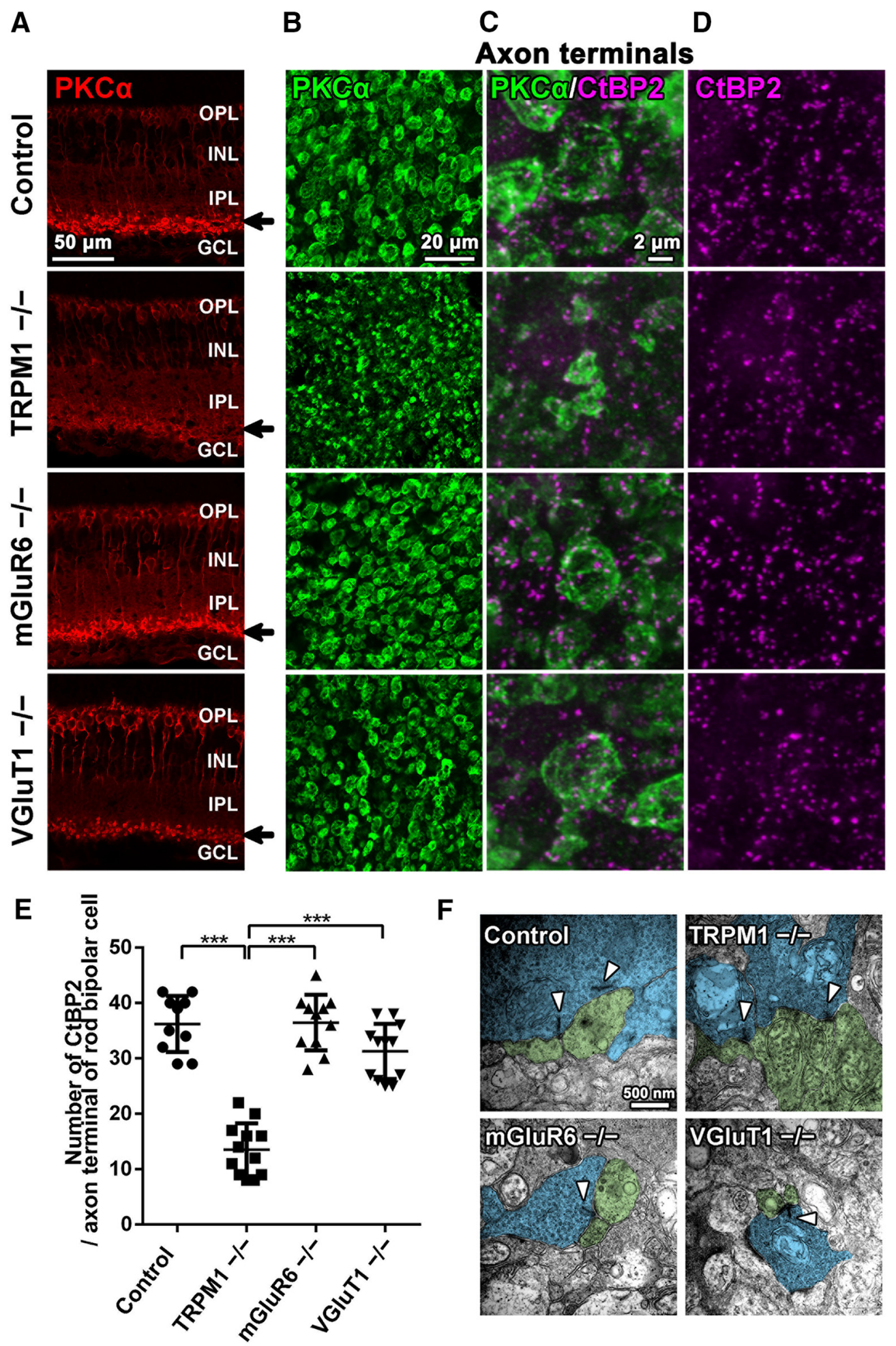

$\mathbf{F}$
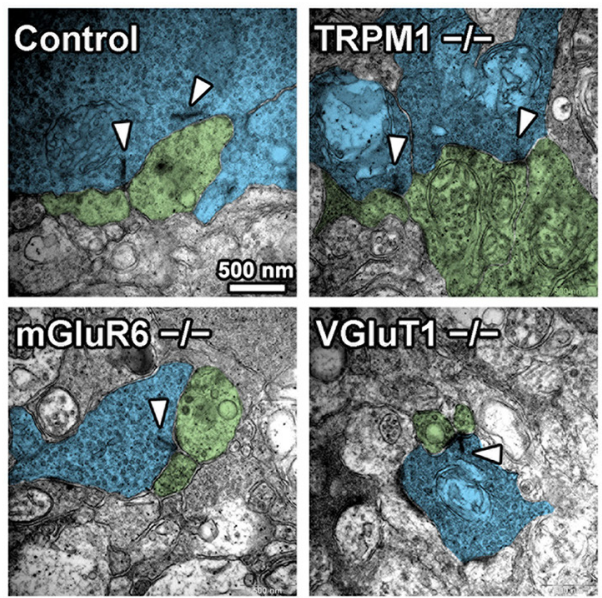

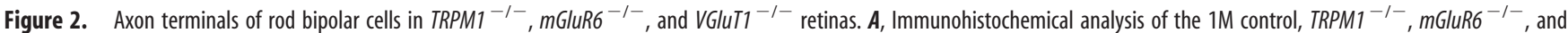
VGluT1 $^{-1-}$ mouse retinas. Retinal sections were immunostained with an antibody against rod bipolar cell marker, PKC $\alpha$ (red). Arrows indicate the axon terminal of rod bipolar cells. GCL, Ganglion

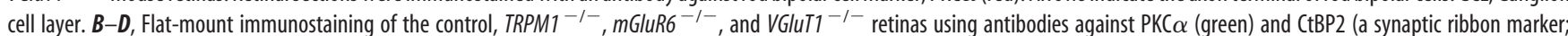
magenta). Axon terminal morphologies of rod bipolar cells are represented. Magnified images of rod bipolar cell axon terminals are shown in $\mathbf{C}$ and $\mathbf{D}$. $\boldsymbol{E}$, The number of $\mathbf{C t B P 2}$ signals contained in an axon terminal of a rod bipolar cell immunostained with the anti-PKC $\alpha$ antibody in control, TRPM1 ${ }^{-1-}$, $m G / u R 6^{-1-}$, and VGluT1 ${ }^{-1-}$ retinas was quantified. ${ }^{* * *} p<0.001$ by one-way ANOVA, posthoc Tukey-Kramer test. Error bars represent \pm SD from the means of $n=10,12,11$, or 12 (control, TRPM1 ${ }^{-1-}$, mGluR6 $^{-1-}$, or VGluT1 ${ }^{-1-}$, respectively) rod bipolar axon terminals collected from individual animals $\left(n=3\right.$ per genotype). $\boldsymbol{F}$, Ultrastructural analysis of rod bipolar cell ribbon synapses in the IPL of control, $T R P M 1^{-1-}$, mGluR6 $^{-1-}$, and VGluT1 ${ }^{-1-}$ mouse retinas at $1 \mathrm{M}$ using electron microscopy. Arrowheads indicate the synaptic ribbons. Bipolar cell axon terminals are tinted blue. Amacrine cell dendrites are tinted green. 
A

C
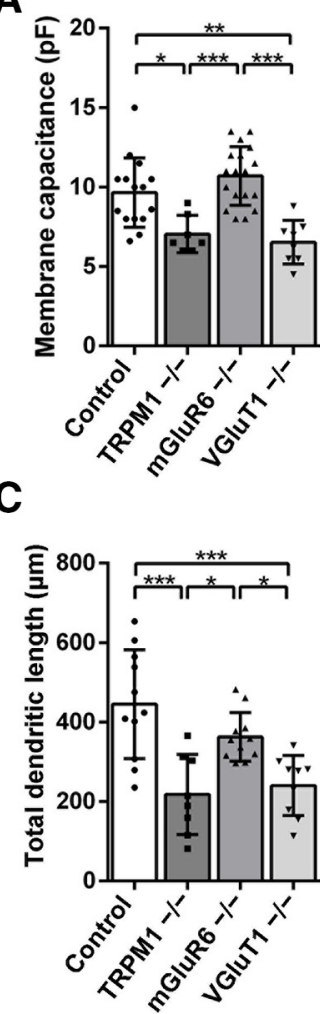

B

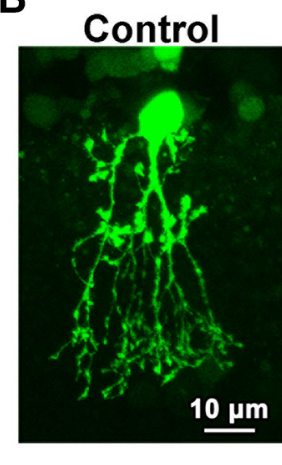

D

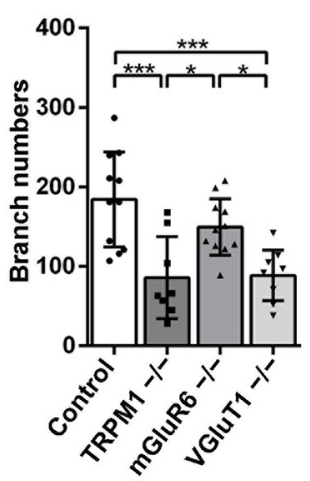

TRPM1 -/-

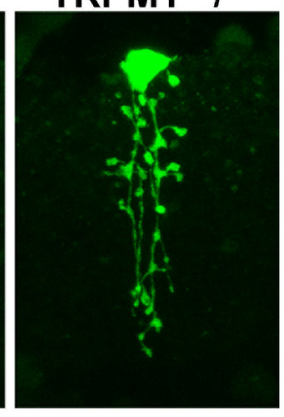

E

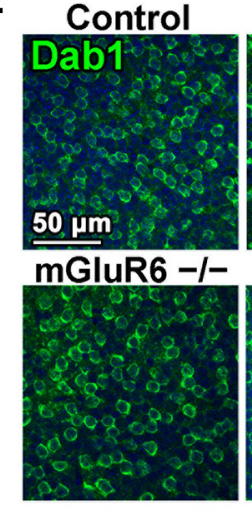

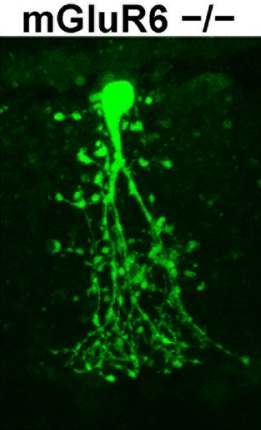

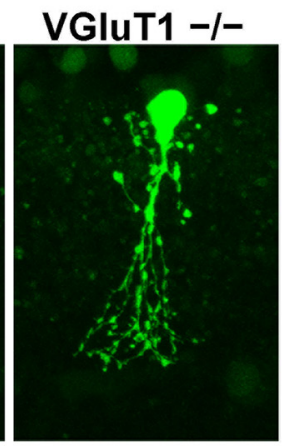

$\mathbf{F}$

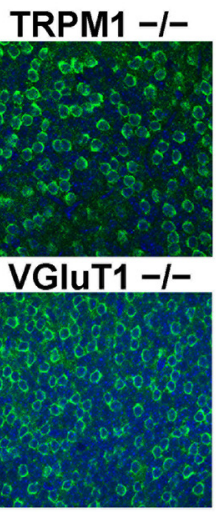

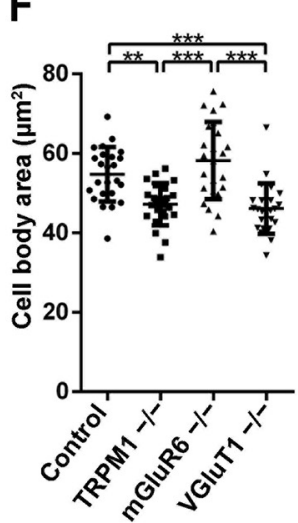

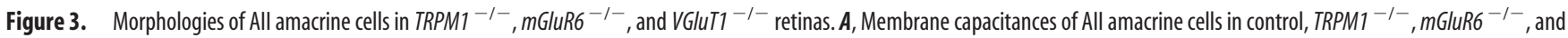
VGluT1 $^{-1-}$ mouse retinas at $1 \mathrm{M}$ are shown. ${ }^{*} p<0.05,{ }^{* *} p<0.01,{ }^{* * *} p<0.001$ by one-way ANOVA, post hoc Tukey-Kramer test. Error bars represent \pm SD from the means of $n=15,7,18$,

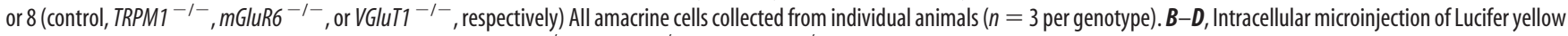
was used to observe All amacrine cell dendrites in control, RRPM $^{-1-}, \mathrm{GGluR6}^{-1-}$, and VGluT1 ${ }^{-1-}$ retinas. Total dendritic length and branch numbers of All amacrine cells are shown in $\mathrm{C}$ and $D$, respectively. ${ }^{*} p<0.05,{ }^{* * *} p<0.001$ by one-way ANOVA, post hoc Tukey-Kramer test. Error bars represent \pm SD from the means of $n=11,8,11$, or 9 (control, TRPM $1^{-1-}$, $m G$ GluR6 ${ }^{-1-}$, or

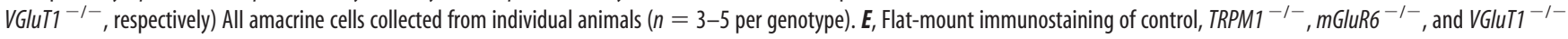
retinas using an antibody against Dab1 (an All amacrine cell marker; green). Cell body morphologies of All amacrine cells are represented. Nuclei were stained with Hoechst (blue). $\boldsymbol{F}$, Cell body areas

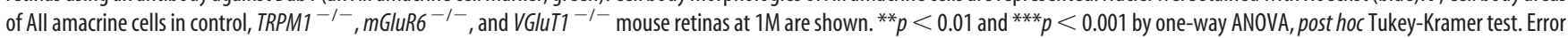
bars represent \pm SD from the means of $n=24$ All amacrine cells collected from individual animals ( $n=3$ per genotype).

cell morphology in the $V G l u T 1^{-1-}$ retina might be caused by the abrogation of synaptic transmission from rod bipolar cells to AII amacrine cells. These results suggest that TRPM1 and VGluT1 are essential for the normal development of AII amacrine cells.

Synaptic connections between photoreceptors and ON bipolar cells are normally constructed in the TRPM1 ${ }^{-1-}$, mGluR6 ${ }^{-1-}$, and $\mathrm{VGluT1}^{-1-}$ retinas

To examine why axon terminal contraction of rod bipolar cells and abnormal AII amacrine cell morphology were observed in the $T R P M 1^{-1-}$ retina, we performed a histological analysis of the ribbon synapse structure among photoreceptors, rod bipolar cells, and horizontal cells in the outer plexiform layer (OPL) by immunostaining retinal sections with antibodies against PKC $\alpha$, CtBP2, PSD95 (a photoreceptor terminal marker), and calbindin (a horizontal cell marker; Fig. $4 A-C)$. Although the horseshoe-shaped structures marked with CtBP2 signals were disrupted in the VGluT1 ${ }^{-1-}$ retina, rod bipolar cell dendrites were correctly guided to photoreceptor terminals in all examined mouse lines (Fig. 4A). In addition, invaginations of rod bipolar cell dendrites into photoreceptor terminals were observed (Fig. $4 B$ ). Horizontal cell processes were also correctly directed to photoreceptor terminals in all examined mouse lines (Fig. 4C). To observe the ultrastructure of photoreceptor ribbon synapses in these mice, we performed conventional electron microscopy analysis (Fig. 4D). In the control retina, we observed the synaptic ribbon structure and the invagination of two ON bipolar cell dendrite terminals and horizontal cell processes. Although the VGluT1 ${ }^{-1-}$ retina exhibited an expansion of synaptic ribbon tips, consistent with the immunohistochemical observation, we observed correct invagination in all examined mouse lines. These results suggest that axon terminal contraction of rod bipolar cells and morphological impairment of AII amacrine cells in the TRPM1 ${ }^{-/-}$retina are not caused by abnormal synaptic connections among photoreceptors, rod bipolar cells, and horizontal cells.

\section{TRPM1 interacts with a constitutively active form of Go $\alpha$}

To elucidate the mechanism underlying the axon terminal contraction of rod bipolar cells and abnormal morphology of AII amacrine cells observed in the TRPM1 ${ }^{-1-}$ retina, we next focused on TRPM1 channel opening and closing in all examined mouse lines. In the TRPM1 $1^{-1-}$ retina, the TRPM1 channel can be regarded as constitutively closed. On the other hand, the TRPM1 channel in the $m G l u R 6^{-1-}$ and $V G l u T 1^{-1-}$ retinas is predicted to open more frequently than that in the control retina, because its opening is negatively regulated by the mGluR6 signaling cascade. Previous electrophysiological analyses have shown that TRPM1 gating is negatively regulated by a Go $\alpha$ subunit coupled with mGluR6 (Koike et al., 2010b) and, moreover, that a consti- 
A
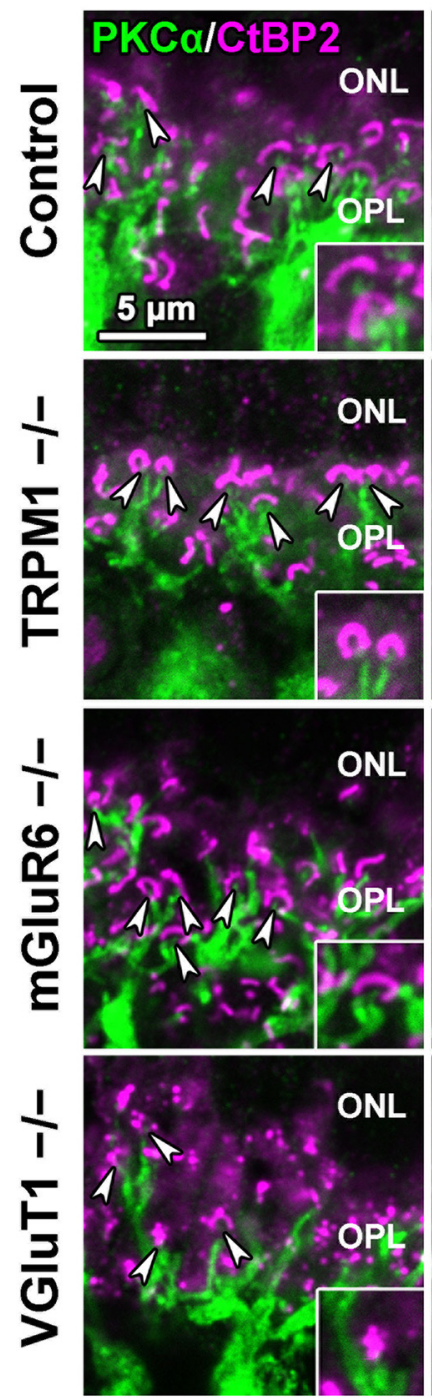

B
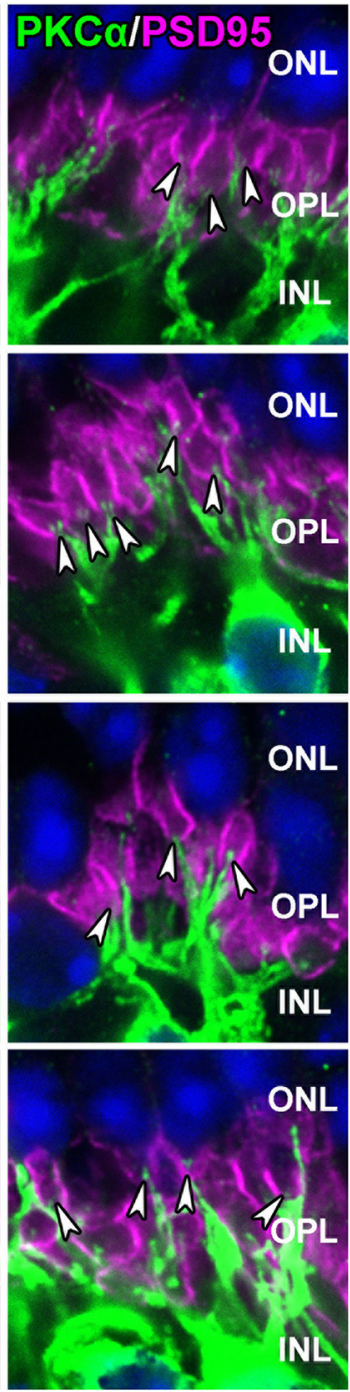

C
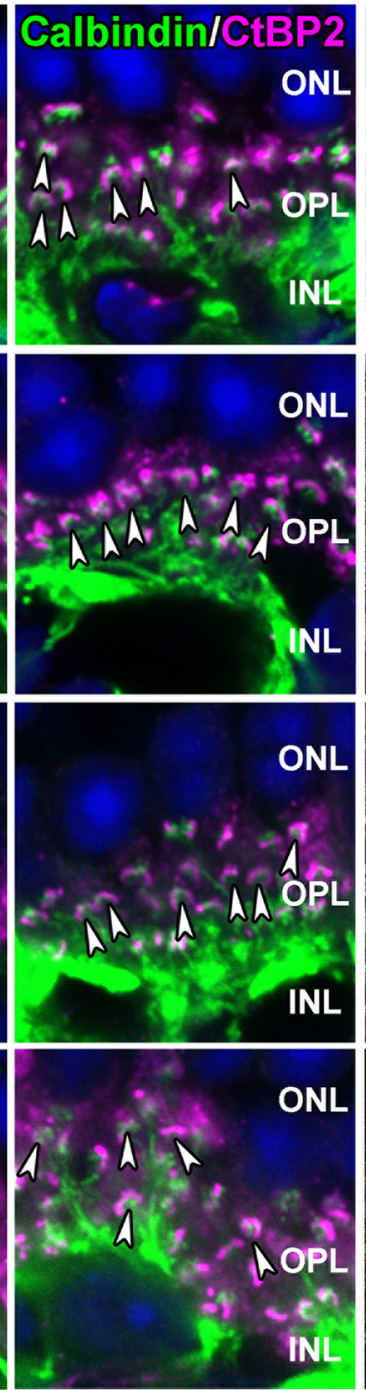

D
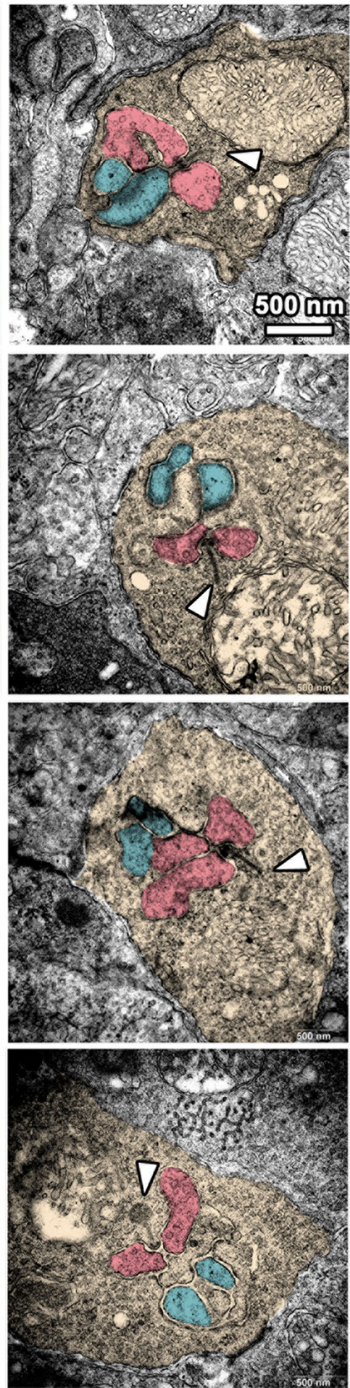

Figure 4. Synaptic connections in the OPL are maintained in $T R P M 1^{-1-}, m G l u R 6^{-1-}$, and VGluT1 ${ }^{-1-}$ retinas. $A-C$, Immunohistochemical analysis of the $1 \mathrm{M}$ control, $T R P M 1^{-/-}$ $\mathrm{mGluR6}^{-1-}$, and VGluT1 ${ }^{-1-}$ mouse retinas using retinal cell marker antibodies as follows: $A$ : PKC $\alpha$ (green) and CtBP2 (magenta); $\boldsymbol{B}$ : PKC $\alpha$ (green) and PSD95 (photoreceptor terminal; magenta); C: calbindin (horizontal cell; green) and CtBP2 (magenta). Nuclei were stained with Hoechst (blue). Arrowheads in $\boldsymbol{A}$ and $\boldsymbol{C}$ indicate rod bipolar dendrites $(\boldsymbol{A})$ or horizontal cell processes $(\boldsymbol{C})$ in the vicinity of photoreceptor ribbons. Arrowheads in $\boldsymbol{B}$ indicate invaginations of rod bipolar cells into photoreceptor terminals $(\boldsymbol{B})$. ONL, Outer nuclear layer. Insets represent OPL regions at high magnification. $\boldsymbol{D}$, Ultrastructural analysis of photoreceptor ribbon synapses in the OPL of control, TRPM1 ${ }^{-1-}$, $m G / u R 6^{-1-}$, and VGluT1 ${ }^{-1-}$ mouse retinas at $1 \mathrm{M}$ by electron microscopy. Arrowheads indicate synaptic ribbons. Photoreceptors are tinted orange. Horizontal cell processes are tinted pink. Bipolar cell dendritic terminals are tinted blue.

tutively active form of $\operatorname{Go} \alpha$, Go $\alpha(\mathrm{Q} 205 \mathrm{~L})$, strongly closes the TRPM1 channel compared with the native form of Go $\alpha$ (Koike et al., 2010b; Xu et al., 2016). To understand the TRPM1 gating mechanism in more detail, we analyzed the interaction between TRPM1 and the native form of Go $\alpha$ or Go $\alpha(\mathrm{Q} 205 \mathrm{~L})$ by immunoprecipitation (Fig. 5A,B). HEK293T cells were transfected with constructs expressing Flag-tagged TRPM1 and HA-tagged Go $\alpha$ or Go $\alpha$ (Q205L). Then cell lysates were immunoprecipitated using an anti-FLAG or an anti-HA antibody. We observed that TRPM1 interacts with both forms of Go $\alpha$, but that TRPM1 more strongly binds to Go $\alpha$ (Q205L) compared with the native form of Go $\alpha$ (Fig. $5 A, B$ ). We also examined the interaction between mGluR6 and the native form of Go $\alpha$ or Go $\alpha$ (Q205L) (Fig. 5C,D). Similar to TRPM1, mGluR6 interacted with both forms of Go $\alpha$, but more strongly interacted with the native form of Go $\alpha$ compared with Go $\alpha(\mathrm{Q} 205 \mathrm{~L})$ (Fig. 5C,D).
Morphogenesis of rod bipolar axon terminals is regulated by TRPM1 channel functions

To assess our hypothesis that developmental abnormalities in rod bipolar cells are attributed to TRPM1 channel closing, we first transfected a plasmid encoding the constitutively active form of Go $\alpha$, which binds to and closes the TRPM1 channel (Fig. 5A, $B$; Koike et al., 2010b; Xu et al., 2016), into wild-type and $m G l u R 6^{-/-}$ retinas using in vivo electroporation at P0 (Fig. $5 E-J$ ). The pCIG plasmid without a cDNA insert was used as a control. We harvested the retinas at $1 \mathrm{M}$ and performed flat-mount immunostaining using anti-GFP and anti-PKC $\alpha$ antibodies (Fig. 5F, $H$ ). We measured the areas of both EGFP- and PKC $\alpha$-positive rod bipolar cell axon terminals (Fig. 5G,I). Overexpression of the constitutively active form of Go $\alpha$ significantly reduced the axon terminal areas of rod bipolar cells in wild-type $\left(t_{(107)}=2.732, p=\right.$ 0.0074 , unpaired Student's $t$ test $)$ and $m G l u R 6^{-1-}$ retinas $\left(t_{(161)}=\right.$ 
2.007, $p=0.0464$, unpaired Student's $t$ test). We also measured the areas of PKC $\alpha$-positive cells without EGFP signals in Go $\alpha(\mathrm{Q} 205 \mathrm{~L})$-transfected mGluR6 ${ }^{-1-}$ retinas as an additional control, and then compared with cells that were both EGFPand PKC $\alpha$-positive. The areas of both EGFP- and PKC $\alpha$-positive cells were significantly reduced compared with those of PKC $\alpha$-positive cells without EGFP signals (Fig. 5J; $t_{(117)}=2.295, p=0.0235$, unpaired Student's $t$ test). We next transfected a channelrhodopsin-2 (ChR2)encoding plasmid, which expresses ChR2 fused with Venus under the control of the 213 bp enhancer sequence of the mouse Grm6 gene, into the TRPM1 ${ }^{-/-}$retina by in vivo electroporation at P0 (Fig. 6A-E). We observed that this enhancer can induce gene expression specifically in retinal ON bipolar cells by in vivo electroporation (Fig. 6B; Lagali et al., 2008). We performed flat-mount immunostaining using anti-GFP and anti-PKC $\alpha$ antibodies and measured the areas of both EGFPand PKC $\alpha$-positive axon terminals of rod bipolar cells (Fig. 6D,E). Overexpression of ChR2 significantly increased the axon terminal areas of rod bipolar cells in the TRPM $1^{-1-}$ retina (Fig. $6 E ; t_{(214)}=2.109$, $p=0.0361$, unpaired Student's $t$ test). We also transfected a plasmid encoding TRPM1(A1068T), known as a constitutively closed form, into the TRPM1 $1^{-1-}$ retina (Peachey et al., 2012; Fig. 6F). Overexpression of native TRPM1 more effectively rescued the areas of rod bipolar axon terminals than TRPM1(A1068T) (Fig. $6 G, H ; t_{(129)}=$ 2.766, $p=0.0065$, unpaired Student's $t$ test). These results suggest that TRPM1 channel opening is essential for the proper formation of rod bipolar cell axon terminals.

Effects of loss of TRPM1, mGluR6, and VGluT1 on morphologies of OFF

bipolar cells

To analyze whether deficiency of TRPM1, mGluR6, or VGluT1 influences OFF cone bipolar cells, we immunostained the retinal sections of wild-type control, TRPM1 ${ }^{-1-}$, $m G l u R 6^{-\prime-}$, and VGluT1 ${ }^{-1-}$ with OFF cone bipolar cell markers for type 2 OFF cone bipolar cells (Znp1) and type 4 OFF cone bipolar cells (Calsenilin). There were no obvious differences in Znp1 signals in the IPL among control, TRPM1 ${ }^{-1-}$, $m G l u R 6^{-1-}$, and VGluT1 $1^{-1-}$ retinas (Fig. $7 A$ ). In contrast, the $V G l u T 1^{-1-}$ retina, but not control, TRPM1 $1^{-1-}$, or mGluR6 ${ }^{-1-}$ retinas, showed a different staining pattern for Calsenilin. Although, in control, $\mathrm{TRPM}^{-1-}$, and $m G l u R 6^{-/-}$retinas,
A

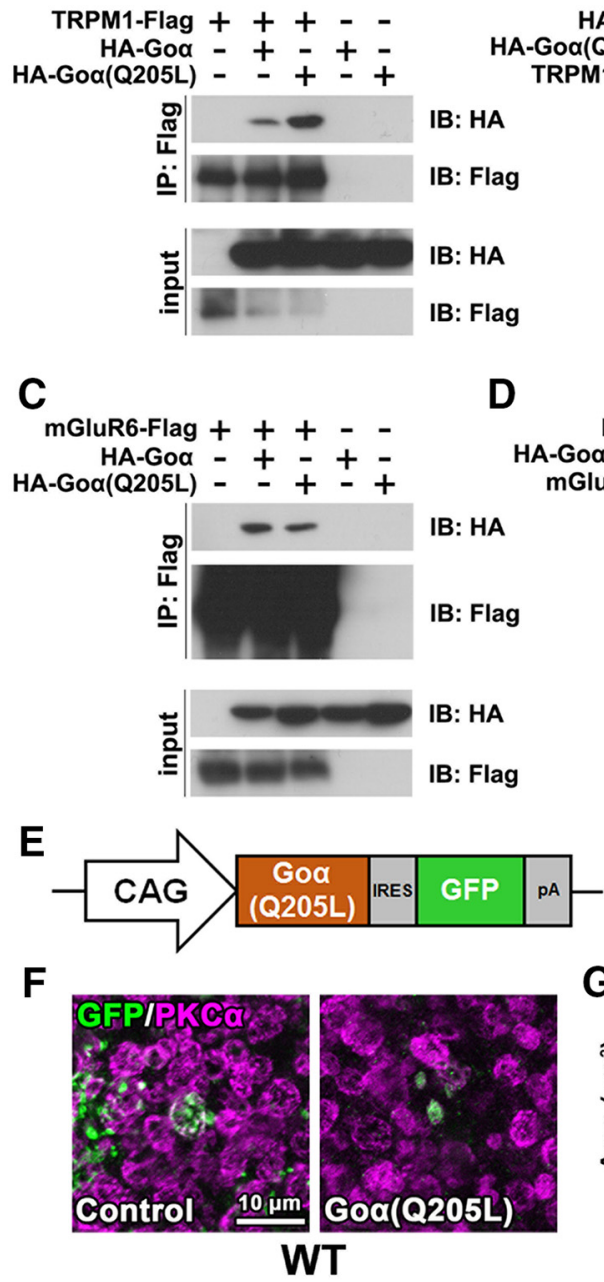

H

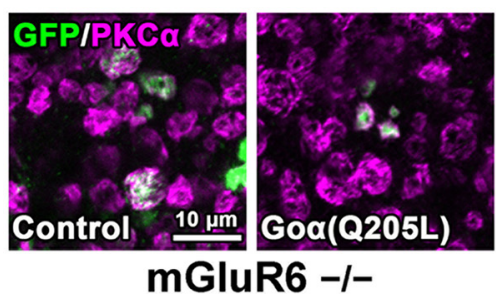

F

WT

mGluR6 -
$\mathrm{HA}-\mathrm{Go \alpha}++-$

Goa(Q205L) - - + +

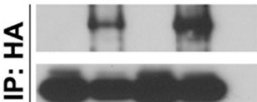

IB: Flag

IB: HA

IB: Flag

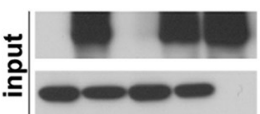

IB: HA

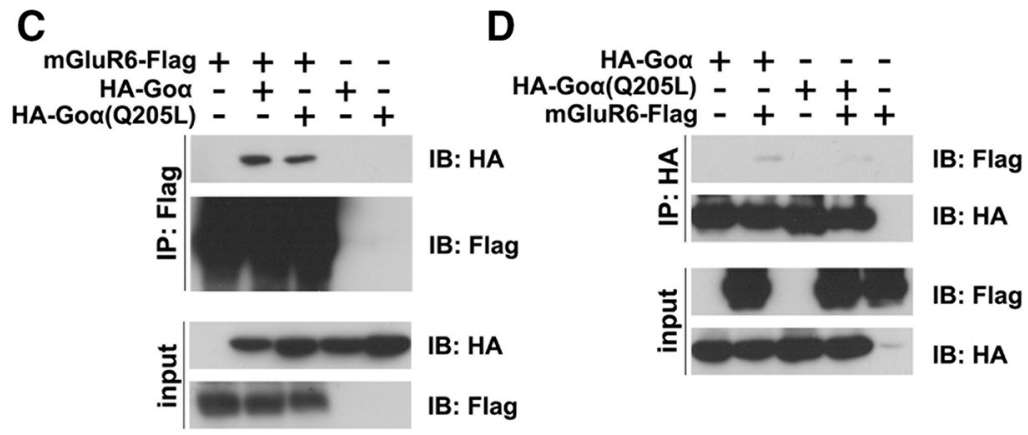

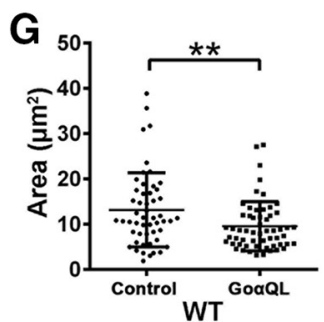

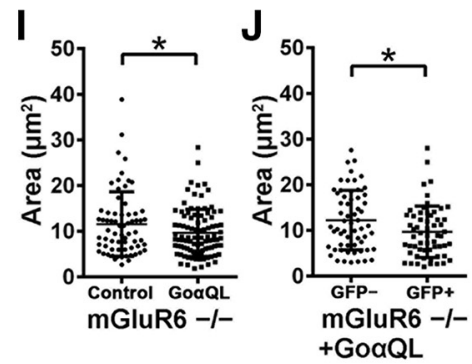

Figure 5. Effect of $G 0 \alpha$ overexpression on axon terminal formation of rod bipolar cells. $A, B$, Interaction of TRPM1 with the Go $\alpha$ subunit. The FLAG-tagged TRPM1 expression plasmid was transfected with HA-tagged Go $\alpha$ or HA-tagged Go $\alpha$ (Q205L) expression plasmids into HEK293T cells $(\boldsymbol{A}, \boldsymbol{B})$. The cell lysates were subjected to immunoprecipitation with either an anti-FLAG $(\boldsymbol{A})$ or an anti-HA antibody (B). Immunoprecipitated proteins were analyzed by Western blotting with anti-FLAG and anti-HA antibodies. $\boldsymbol{C}$, D, Interaction of mGluR6 with the Go $\alpha$ subunit. The FLAG-tagged mGluR6 expression plasmid was transfected with HA-tagged Go $\alpha$ or HA-tagged Go $\alpha$ (Q205L) expression plasmids into HEK293T cells $(\boldsymbol{C}, \boldsymbol{D})$. The cell lysates were subjected to immunoprecipitation with either an anti-FLAG $(\boldsymbol{C})$ or an anti-HA antibody (D). $\boldsymbol{E}$, Schematic representation of the expression construct of Go $\alpha$ (Q205L) (pCIG-Go $\alpha\left(\right.$ Q205L)) used for in vivo electroporation into P0 wild-type and $m G$ luR6 ${ }^{-1-}$ mouse retinas. $F$, The pCIG

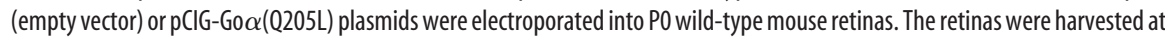
1M, spread flat, and immunostained with antibodies against GFP (green) and PKC $\alpha$ (magenta). The electroporated cells express EGFP mediated by the IRES sequence. $G$, Axon terminal areas of both EGFP- and PKC $\alpha$-positive cells were measured. ${ }^{* *} p<0.01$ by unpaired Student's $t$ test. Error bars represent \pm SD from the means of $n=52$ or 57 [control or Go $\alpha(Q 205 \mathrm{~L})$, respectively] rod bipolar axon terminals collected from individual animals $(n=3)$. $\boldsymbol{H}$, The $\mathrm{pCIG}$ (empty vector) or $\mathrm{pCIG-Go} \alpha(0205 \mathrm{~L})$ plasmids were electroporated into PO mGluR6 ${ }^{-I-}$ mouse retinas. I, Axon terminal areas of both EGFP- and PKC $\alpha$-positive cells were measured. ${ }^{*} p<0.05$ by unpaired Student's $t$ test. Error bars represent \pm SD from the means of $n=67$ or 96 [control or Go $\alpha(Q 205 \mathrm{~L})$, respectively] rod bipolar axon terminals collected from individual animals $(n=3)$. J, Axon terminal areas of cells that were both EGFP- and PKC $\alpha$-positive are compared with axon terminal areas of PKC $\alpha$-positive cells without EGFP signals in Go $\alpha($ Q205L) transfected retinas. ${ }^{*} p<0.05$ by unpaired Student's ttest. Errorbars represent \pm SD from the means of $n=60$ or 59 (EGFP-negative or EGFP-positive, respectively) rod bipolar axon terminals collected from individual animals $(n=3)$. Go $\alpha \mathrm{QL}, \mathrm{Go} \alpha(\mathrm{Q} 205 \mathrm{~L})$. 
A

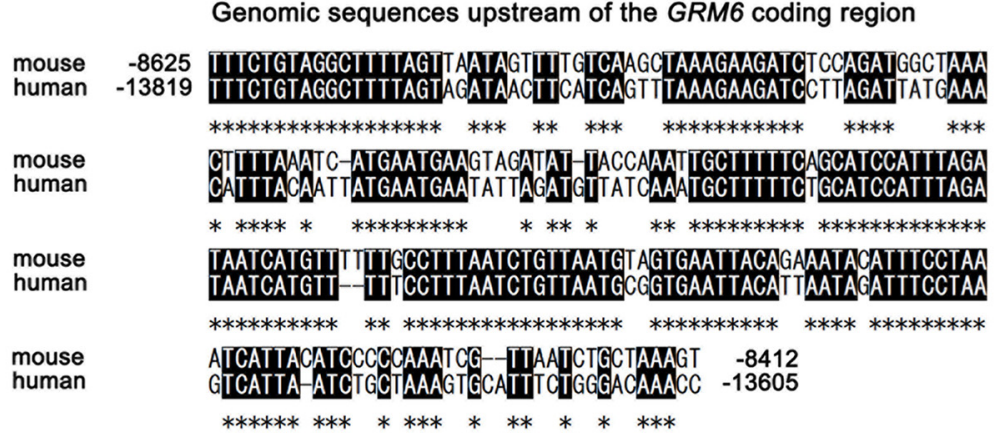

B

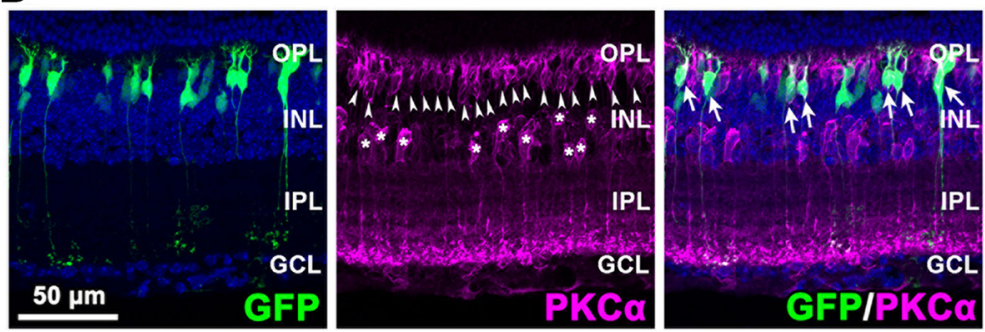

C

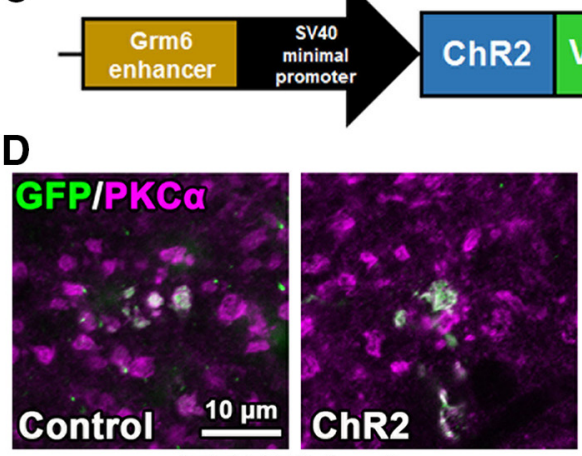
TRPM1 -I-

$\mathbf{F}$

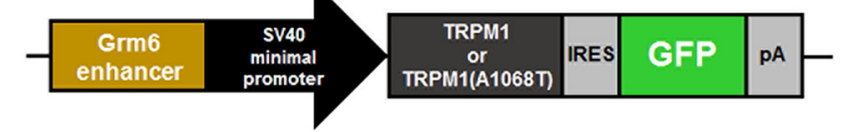

G

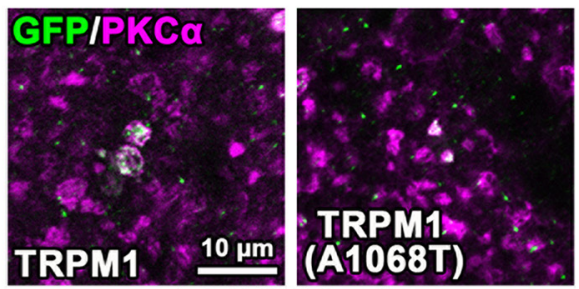

TRPM1 -I-

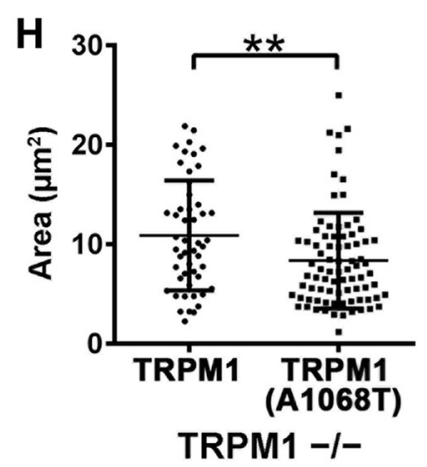

Figure 6. Effect of channel opening on axon terminal formation of rod bipolar cells. $\boldsymbol{A}$, The 213-base pair mouse genomic sequence used as a Grm6 enhancer was aligned to the corresponding region in human genome. The numbers indicate nucleotide positions relative to the ATG start codon of the mouse Grm6 or the human GRM6 gene. Asterisks show identical sequences. B, pGrm6-EGFP plasmids were electroporated into P0 wild-type mouse retinas. The electroporated retinas were harvested at 1M and immunostained with antibodies against GFP (green) and PKC $\alpha$ (magenta). The electroporated cells were marked with green fluorescence. Nuclei were stained with Hoechst (blue). Asterisks indicate PKC $\alpha$-positive amacrine cells. Arrowheads indicate rod bipolar cells. Arrows indicate GFP-positive rod bipolar cells. C, Schematic representation of the expression construct of ChR2 (pGrm6-ChR2 + Venus) used for in vivo electroporation into PO TRPM1 ${ }^{-1-}$ mouse retinas. D, The pGrm6-EGFP (empty vector) or
Calsenilin signals were divided into two layers in the IPL, in the VGluT1 $1^{-/-}$retina, those signals exhibited a single-layer structure in the IPL (Fig. 7B). These results suggest that TRPM1 is dispensable for OFF cone bipolar cell development.

\section{Discussion}

In the current study, we found a remarkable contraction of rod bipolar cell axon terminals and a decreased number of synaptic connections between rod bipolar and amacrine cells in the TRPM1 ${ }^{-1-}$ retina, but not in the $m G l u R 6^{-1-}$ or VGluT1 ${ }^{-1-}$ retinas (Figs. 2A-E, 8). Why did these no b-wave mouse lines show these phenotypic differences? We observed that there are no obvious defects in the synaptic connections constructed by photoreceptor, rod bipolar, and horizontal cells in the OPL among these mice by immunohistochemical and electron microscopic analyses (Fig. 4). Therefore, the results suggest that the defects in rod bipolar cell development observed in the TRPM1 ${ }^{-/-}$retina are not caused by abnormal synaptic connections among photoreceptor, rod bipolar, and horizontal cells in the OPL. Although it was previously reported that the number of invaginations of ON bipolar cell dendrites into photoreceptor terminals is reduced in the nob4 mouse retina, in which mGluR6 does not localize to the tips of ON bipolar cell dendrites, by electron microscopy (Cao et al., 2009), we did not observe those changes. Our results support a previous report showing that the number of invaginations of $\mathrm{ON}$ bipo-

$\leftarrow$

pGrm6-ChR2 + Venus plasmids were electroporated into PO TRPM1 ${ }^{-1-}$ mouse retinas. The retinas were harvested at $1 \mathrm{M}$, spread flat, and immunostained with antibodies against GFP (green) and PKC $\alpha$ (magenta). The electroporated cells were marked with green fluorescence. $\boldsymbol{E}$, Axon terminal areas of both green fluorescence- and PKC $\alpha$-positive cells were measured. ${ }^{*} p<0.05$ by unpaired Student's $t$ test. Error bars represent \pm SD from the means of $n=106$ or 110 (control or ChR2, respectively) rod bipolar axon terminals collected from individual animals $(n=3-4) . \boldsymbol{F}$, Schematic representation of the expression construct of native TRPM1 or a constitutively closed form of TRPM1, TRPM1(A1068T), used for in vivo electroporation into P0 TRPM1 ${ }^{-1-}$ mouse retinas. G, The pGrm6TRPM1-IRES-EGFP or pGrm6-TRPM1(A1068T)-IRES-EGFP plasmids were electroporated into PO TRPM1 ${ }^{-1-}$ mouse retinas. The retinas were harvested at $1 \mathrm{M}$, spread flat, and immunostained with antibodies against GFP (green) and PKC $\alpha$ (magenta). The electroporated cells were marked with green fluorescence. $\boldsymbol{H}$, Axon terminal areas of both green fluorescence- and PKC $\alpha$-positive cells were measured. ${ }^{* *} p<$ 0.01 by unpaired Student's $t$ test. Error bars represent \pm SD from the means of $n=50$ or 81 [TRPM1 or TRPM1(A1068T), respectively] rod bipolar axon terminals collected from individual animals $(n=3)$. 


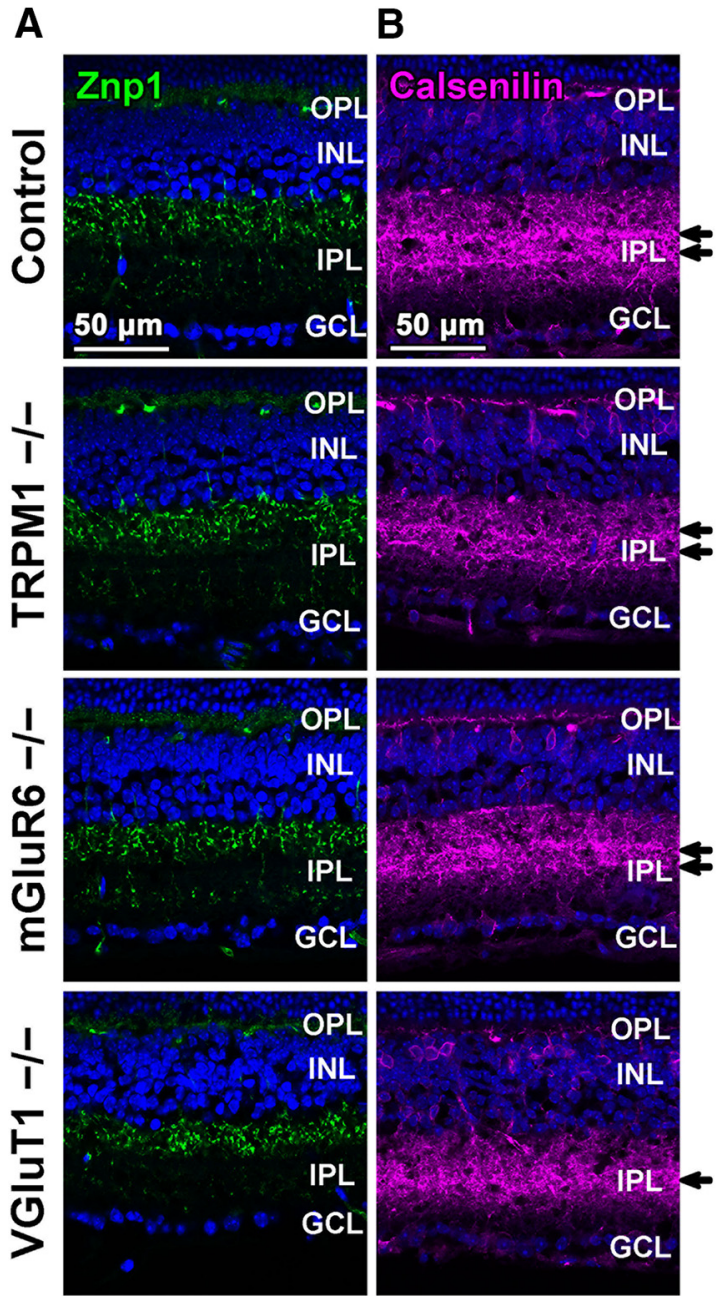

Figure 7. Immunohistochemical analysis of OFF cone bipolar cells in TRPM1 ${ }^{-1-}$, mGluR6 ${ }^{-1-}$, and VGluT1 ${ }^{-1-}$ retinas. $\boldsymbol{A}, \boldsymbol{B}$, Retinal sections obtained from $1 \mathrm{M}$ control, TRPM1 $^{-1-}$, GluR6 $^{-1-}$, and VGluT1 ${ }^{-1-}$ mice were immunostained with an anti-Znp1 (a type 2 OFF bipolar cell marker; $\boldsymbol{A}$, green) or an anti-Calsenilin antibody (a type 4 OFF bipolar cell marker; $\boldsymbol{B}$, magenta). Nuclei were stained with Hoechst (blue). Arrows indicate axon terminal layers immunostained by the anti-Calsenilin antibody.

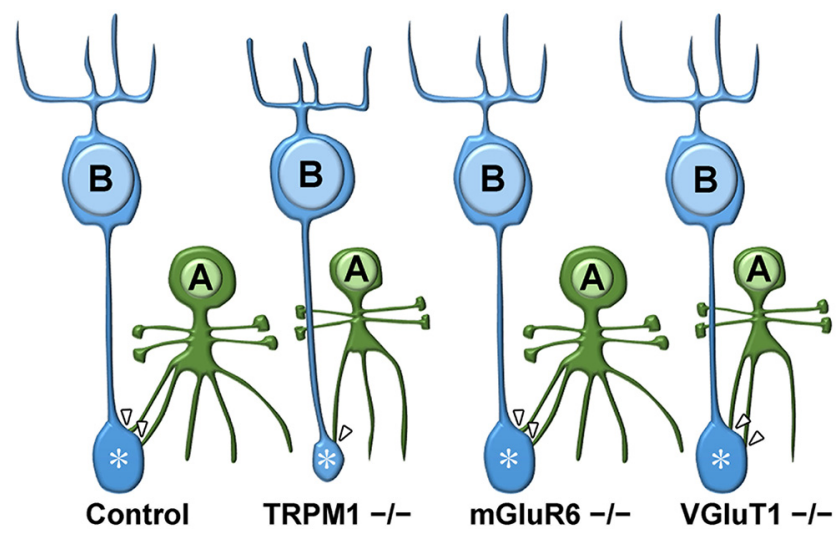

Figure 8. Schematic representation of rod bipolar cells and All amacrine cells in the control,

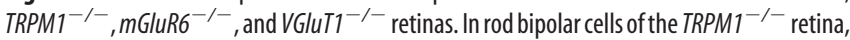
axon terminal areas and numbers of synaptic connections with amacrine cells are reduced. In All amacrine cells of $T_{R P M}{ }^{-1-}$ and VGluT1 ${ }^{-1-}$ retinas, total dendritic length, branch numbers, and cell body size are reduced. B, Rod bipolar cell; A, All amacrine cell. Arrowheads indicate synapses with All amacrine cells. Asterisks indicate axon terminals of rod bipolar cells. lar cells is unaltered in the $m G l u R 6^{-1-}$ retina (Tsukamoto and Omi, 2014). This discrepancy might be due to the differences in mouse strains. We next focused on the TRPM1 channel opening and closing in all examined mouse lines. In contrast to the mGluR6 ${ }^{-1-}$ or VGluT1 $1^{-1-}$ retina, in the TRPM1 $1^{-1-}$ retina, the TRPM1 channel can be regarded as being constitutively closed. To investigate the role of TRPM1 channel function in axon terminal formation of rod bipolar cells, we transfected a construct expressing Go $\alpha(\mathrm{Q} 205 \mathrm{~L})$, which closes the TRPM1 channel (Koike et al., 2010b; Xu et al., 2016), into wild-type and mGluR6 ${ }^{-1-}$ retinas by in vivo electroporation (Fig. 5E-J). Go $\alpha(\mathrm{Q} 205 \mathrm{~L})$ induced significant contraction of rod bipolar axon terminals in the wild-type retina as well as in the $m G l u R 6^{-1-}$ retina, where the TRPM1 channel is predicted to open more frequently than in the wild-type retina. In addition, we transfected the construct expressing ChR2 as a substitute for the TRPM1 channel into the TRPM1 ${ }^{-/-}$retina (Fig. $6 C-E$ ). It was previously reported that transduction of ChR2 in the retina lacking light perception rescues light-aversion behavior in mice under daylight conditions (Semo et al., 2010). We therefore suspected that ChR2 can function to some extent in ON bipolar cells of the TRPM1 ${ }^{-/-}$retina. To achieve efficient channel opening, we used ChR2(C128S), which has a 300-fold stronger light sensitivity than native ChR2 (Berndt et al., 2009). ChR2 significantly rescued the abnormal axon terminal morphologies of rod bipolar cells in the TRPM1 ${ }^{-1-}$ retina. We also found that overexpression of native TRPM1 significantly rescues the areas of rod bipolar axon terminals when compared with TRPM1(A1068T) in the TRPM1 ${ }^{-1-}$ retina (Fig. $6 F-H$ ). Together, these results suggest that TRPM1 channel opening is essential for synapse formation between rod bipolar and amacrine cells as well as axon terminal formation of rod bipolar cells.

We observed the morphologies of rod bipolar cells using an anti-PKC $\alpha$ antibody by immunohistochemical analysis (Figs. $2 A-C, 4 A, B, 5 F, H, 6 B, D, G)$. PKC $\alpha$, a calcium-dependent serine-threonine kinase, is specifically expressed in rod bipolar cells and a subset of amacrine cells in the retina (Negishi et al., 1988; Greferath et al., 1990). The observed contraction of rod bipolar cell axon terminals in the TRPM1 $1^{-1-}$ retina might be caused by subcellular localization changes of $\mathrm{PKC} \alpha$ proteins. However, when we transfected a construct expressing GFP into the TRPM1 ${ }^{-1-}$ retina (Fig. $6 D$ ), the size of GFP and PKC $\alpha$ signals in rod bipolar axon terminals was almost the same. Because GFP generally diffuses throughout a cell, it is strongly suggested that $\mathrm{PKC} \alpha$ signals in the rod bipolar axon terminal reflected the axon terminal morphology of rod bipolar cells.

We found that the membrane capacitance of AII amacrine cells in the TRPM1 $1^{-1-}$ retina is significantly reduced compared with that of control and $m G l u R 6^{-1-}$ retinas (Fig. $3 A$ ). This result suggests that the cell membrane area of AII amacrine cells in the TRPM $1^{-1-}$ retina is reduced compared with that of control and $m G l u R 6^{-1-}$ retinas. Indeed, the total dendritic length, branch numbers, and cell body size of AII amacrine cells decreased in the TRPM $1^{-1-}$ retina (Fig. $3 B-F$ ). Because inhibition of presynaptic glutamate release can change the morphology of postsynaptic neurons in the brain (De Marco García et al., 2015), we hypothesized that abnormal morphology of AII amacrine cells in the TRPM1 $1^{-/-}$retina results from a decrease in absolute quantities of released glutamates through the decreased number of synaptic connections between rod bipolar and AII amacrine cells (Fig. 8). On the other hand, AII amacrine cells in the VGluT1 ${ }^{-1-}$ retina showed impaired morphology regardless of the correct formation of rod bipolar cell axon terminals. It is known that VGluT1 is 
expressed not only in photoreceptors, but also in bipolar cells (Johnson et al., 2003). Although all VGluT proteins, VGluT1, 2, and 3 , are expressed in the retina, VGluT2 and 3 expression in bipolar cells has not been detected (Sherry et al., 2003). Accordingly, it is strongly suggested that there is no glutamate release from rod bipolar cells in the VGluT1 ${ }^{-1-}$ retina. Our observations in the VGluT1 ${ }^{-1-}$ retina support the hypothesis that abnormal morphology of AII amacrine cells in the TRPM1 ${ }^{-1-}$ retina is dependent on a decrease in glutamate release from rod bipolar cells.

We examined the morphologies of OFF cone bipolar cells among control, TRPM1 $1^{-/-}$, mGluR6 ${ }^{-1-}$, and VGluT1 ${ }^{-1-}$ mice by immunostaining using anti-Znp1 and anti-Calsenilin antibodies (Fig. $7 A, B$ ), because OFF cone bipolar cells receive glycinergic inputs from AII amacrine cells (Wässle, 2004). There were no obvious differences in morphologies of OFF cone bipolar cells among the control, TRPM $1^{-1-}$ and $m G l u R 6^{-1-}$ retinas. On the other hand, axonal projection abnormalities of type 4 OFF cone bipolar cells were observed in the VGluT1 ${ }^{-1-}$ retina. Because these alterations were not observed in the TRPM1 ${ }^{-1-}$ retina, which showed impaired AII amacrine cell morphology similar to the $V G l u T 1^{-1-}$ retina (Fig. $3 B-F$ ), we speculated that axonal projection abnormalities of type 4 OFF cone bipolar cells in the VGluT1 ${ }^{-1-}$ retina are attributed to inhibition of synaptic transmissions between photoreceptors and OFF bipolar cells rather than to abnormalities in AII amacrine cells.

\section{References}

Berndt A, Yizhar O, Gunaydin LA, Hegemann P, Deisseroth K (2009) Bistable neural state switches. Nat Neurosci 12:229-234. CrossRef Medline

Bloomfield SA, Dacheux RF (2001) Rod vision: pathways and processing in the mammalian retina. Prog Retin Eye Res 20:351-384. CrossRef Medline

Bodnarenko SR, Chalupa LM (1993) Stratification of ON and OFF ganglion cell dendrites depends on glutamate-mediated afferent activity in the developing retina. Nature 364:144-146. CrossRef Medline

Cao Y, Masuho I, Okawa H, Xie K, Asami J, Kammermeier PJ, Maddox DM, Furukawa T, Inoue T, Sampath AP, Martemyanov KA (2009) Retinaspecific GTPase accelerator RGS11/G beta 5S/R9AP is a constitutive heterotrimer selectively targeted to mGluR6 in ON-bipolar neurons. J Neurosci 29:9301-9313. CrossRef Medline

Cembrowski MS, Logan SM, Tian M, Jia L, Li W, Kath WL, Riecke H, Singer JH (2012) The mechanisms of repetitive spike generation in an axonless retinal interneuron. Cell Rep 1:155-166. CrossRef Medline

Chaya T, Omori Y, Kuwahara R, Furukawa T (2014) ICK is essential for cell type-specific ciliogenesis and the regulation of ciliary transport. EMBO J 33:1227-1242. CrossRef Medline

De Marco García NV, Priya R, Tuncdemir SN, Fishell G, Karayannis T (2015) Sensory inputs control the integration of neurogliaform interneurons into cortical circuits. Nat Neurosci 18:393-401. CrossRef Medline

Demb JB, Singer JH (2012) Intrinsic properties and functional circuitry of the AII amacrine cell. Vis Neurosci 29:51-60. CrossRef Medline

Dunn FA, Della Santina L, Parker ED, Wong RO (2013) Sensory experience shapes the development of the visual system's first synapse. Neuron 80 : 1159-1166. CrossRef Medline

Freed MA, Smith RG, Sterling P (1987) Rod bipolar array in the cat retina: pattern of input from rods and GABA-accumulating amacrine cells. J Comp Neurol 266:445-455. CrossRef Medline

Ghosh KK, Bujan S, Haverkamp S, Feigenspan A, Wässle H (2004) Types of bipolar cells in the mouse retina. J Comp Neurol 469:70-82. CrossRef Medline

Greferath U, Grünert U, Wässle H (1990) Rod bipolar cells in the mammalian retina show protein kinase C-like immunoreactivity. J Comp Neurol 301:433-442. CrossRef Medline

Hoon M, Sinha R, Okawa H, Suzuki SC, Hirano AA, Brecha N, Rieke F, Wong RO (2015) Neurotransmission plays contrasting roles in the maturation of inhibitory synapses on axons and dendrites of retinal bipolar cells. Proc Natl Acad Sci U S A 112:12840-12845. CrossRef Medline

Hua JY, Smith SJ (2004) Neural activity and the dynamics of central nervous system development. Nat Neurosci 7:327-332. CrossRef Medline
Hubel DH, Wiesel TN (1962) Receptive fields, binocular interaction and functional architecture in the cat's visual cortex. J Physiol 160:106-154. CrossRef Medline

Irie S, Sanuki R, Muranishi Y, Kato K, Chaya T, Furukawa T (2015) Rax homeoprotein regulates photoreceptor cell maturation and survival in association with Crx in the postnatal mouse retina. Mol Cell Biol 35:25832596. CrossRef Medline

Ishii M, Morigiwa K, Takao M, Nakanishi S, Fukuda Y, Mimura O, Tsukamoto Y (2009) Ectopic synaptic ribbons in dendrites of mouse retinal ON- and OFF-bipolar cells. Cell Tissue Res 338:355-375. CrossRef Medline

Johnson J, Tian N, Caywood MS, Reimer RJ, Edwards RH, Copenhagen DR (2003) Vesicular neurotransmitter transporter expression in developing postnatal rodent retina: GABA and glycine precede glutamate. J Neurosci 23:518-529. Medline

Johnson J, Fremeau RT Jr, Duncan JL, Rentería RC, Yang H, Hua Z, Liu X, LaVail MM, Edwards RH, Copenhagen DR (2007) Vesicular glutamate transporter 1 is required for photoreceptor synaptic signaling but not for intrinsic visual functions. J Neurosci 27:7245-7255. CrossRef Medline

Kerschensteiner D, Morgan JL, Parker ED, Lewis RM, Wong RO (2009) Neurotransmission selectively regulates synapse formation in parallel circuits in vivo. Nature 460:1016-1020. CrossRef Medline

Koike C, Numata T, Ueda H, Mori Y, Furukawa T (2010a) TRPM1: a vertebrate TRP channel responsible for retinal ON bipolar function. Cell Calcium 48:95-101. CrossRef Medline

Koike C, Obara T, Uriu Y, Numata T, Sanuki R, Miyata K, Koyasu T, Ueno S, Funabiki K, Tani A, Ueda H, Kondo M, Mori Y, Tachibana M, Furukawa T (2010b) TRPM1 is a component of the retinal ON bipolar cell transduction channel in the mGluR6 cascade. Proc Natl Acad Sci U S A 107: 332-337. CrossRef Medline

Kolb H, Famiglietti EV (1974) Rod and cone pathways in the inner plexiform layer of cat retina. Science 186:47-49. CrossRef Medline

Lagali PS, Balya D, Awatramani GB, Münch TA, Kim DS, Busskamp V, Cepko CL, Roska B (2008) Light-activated channels targeted to ON bipolar cells restore visual function in retinal degeneration. Nat Neurosci 11:667675. CrossRef Medline

Manookin MB, Beaudoin DL, Ernst ZR, Flagel LJ, Demb JB (2008) Disinhibition combines with excitation to extend the operating range of the OFF visual pathway in daylight. J Neurosci 28:4136-4150. CrossRef Medline

Matsuda T, Cepko CL (2004) Electroporation and RNA interference in the rodent retina in vivo and in vitro. Proc Natl Acad Sci U S A 101:16-22. CrossRef Medline

Mørkve SH, Veruki ML, Hartveit E (2002) Functional characteristics of non-NMDA-type ionotropic glutamate receptor channels in AII amacrine cells in rat retina. J Physiol 542:147-165. CrossRef Medline

Negishi K, Kato S, Teranishi T (1988) Dopamine cells and rod bipolar cells contain protein kinase C-like immunoreactivity in some vertebrate retinas. Neurosci Lett 94:247-252. CrossRef Medline

Neher E, Marty A (1982) Discrete changes of cell membrane capacitance observed under conditions of enhanced secretion in bovine adrenal chromaffin cells. Proc Natl Acad Sci U S A 79:6712-6716. CrossRef Medline

Nomura A, Shigemoto R, Nakamura Y, Okamoto N, Mizuno N, Nakanishi S (1994) Developmentally regulated postsynaptic localization of a metabotropic glutamate receptor in rat rod bipolar cells. Cell 77:361-369. CrossRef Medline

Okawa H, Della Santina L, Schwartz GW, Rieke F, Wong RO (2014) Interplay of cell-autonomous and nonautonomous mechanisms tailors synaptic connectivity of converging axons in vivo. Neuron 82:125-137. CrossRef Medline

Omori Y, Kitamura T, Yoshida S, Kuwahara R, Chaya T, Irie S, Furukawa T (2015) Mef2d is essential for the maturation and integrity of retinal photoreceptor and bipolar cells. Genes Cells 20:408-426. CrossRef Medline

Peachey NS, Pearring JN, Bojang P Jr, Hirschtritt ME, Sturgill-Short G, Ray TA, Furukawa T, Koike C, Goldberg AF, Shen Y, McCall MA, Nawy S, Nishina PM, Gregg RG (2012) Depolarizing bipolar cell dysfunction due to a Trpm1 point mutation. J Neurophysiol 108:2442-2451. CrossRef Medline

Sanuki R, Watanabe S, Sugita Y, Irie S, Kozuka T, Shimada M, Ueno S, Usukura J, Furukawa T (2015) Protein-4.1G-mediated membrane trafficking is essential for correct rod synaptic location in the retina and for normal visual function. Cell Rep 10:796-808. CrossRef Medline

Semo M, Gias C, Ahmado A, Sugano E, Allen AE, Lawrence JM, Tomita H, Coffey PJ, Vugler AA (2010) Dissecting a role for melanopsin in behav- 
ioural light aversion reveals a response independent of conventional photoreception. PLoS One 5:e15009. CrossRef Medline

Shen Y, Rampino MA, Carroll RC, Nawy S (2012) G-protein-mediated inhibition of the Trp channel TRPM1 requires the G $\beta \gamma$ dimer. Proc Natl Acad Sci U S A 109:8752-8757. CrossRef Medline

Sherry DM, Wang MM, Bates J, Frishman LJ (2003) Expression of vesicular glutamate transporter 1 in the mouse retina reveals temporal ordering in development of rod vs. cone and ON vs. OFF circuits. J Comp Neurol 465:480-498. CrossRef Medline

Strettoi E, Raviola E, Dacheux RF (1992) Synaptic connections of the narrow-field, bistratified rod amacrine cell (AII) in the rabbit retina. J Comp Neurol 325:152-168. CrossRef Medline

Strettoi E, Dacheux RF, Raviola E (1994) Cone bipolar cells as interneurons in the rod pathway of the rabbit retina. J Comp Neurol 347:139-149. CrossRef Medline

Tamalu F, Watanabe S (2007) Glutamatergic input is coded by spike frequency at the soma and proximal dendrite of AII amacrine cells in the mouse retina. Eur J Neurosci 25:3243-3252. CrossRef Medline

Tian N, Copenhagen DR (2003) Visual stimulation is required for refinement of ON and OFF pathways in postnatal retina. Neuron 39:85-96. CrossRef Medline

Tsukamoto Y, Omi N (2014) Effects of mGluR6-deficiency on photoreceptor ribbon synapse formation: comparison of electron microscopic analysis of serial sections with random sections. Vis Neurosci 31:39-46. CrossRef Medline

Veruki ML, Hartveit E (2002a) Electrical synapses mediate signal transmission in the rod pathway of the mammalian retina. J Neurosci 22:1055810566. Medline

Veruki ML, Hartveit E (2002b) AII (Rod) amacrine cells form a network of electrically coupled interneurons in the mammalian retina. Neuron 33 : 935-946. CrossRef Medline

Veruki ML, Mørkve SH, Hartveit E (2003) Functional properties of spontaneous EPSCs and non-NMDA receptors in rod amacrine (AII) cells in the rat retina. J Physiol 549:759-774. CrossRef Medline

Wan QF, Zhou ZY, Thakur P, Vila A, Sherry DM, Janz R, Heidelberger R (2010) SV2 acts via presynaptic calcium to regulate neurotransmitter release. Neuron 66:884-895. CrossRef Medline

Wässle H (2004) Parallel processing in the mammalian retina. Nat Rev Neurosci 5:747-757. CrossRef Medline

Wässle H, Grünert U, Chun MH, Boycott BB (1995) The rod pathway of the macaque monkey retina: identification of AII-amacrine cells with antibodies against calretinin. J Comp Neurol 361:537-551. CrossRef Medline

Watanabe S, Sanuki R, Sugita Y, Imai W, Yamazaki R, Kozuka T, Ohsuga M, Furukawa T (2015) Prdm13 regulates subtype specification of retinal amacrine interneurons and modulates visual sensitivity. J Neurosci 35: 8004-8020. CrossRef Medline

Xu HP, Tian N (2007) Retinal ganglion cell dendrites undergo a visual activity-dependent redistribution after eye opening. J Comp Neurol 503: 244-259. CrossRef Medline

Xu Y, Dhingra A, Fina ME, Koike C, Furukawa T, Vardi N (2012) mGluR6 deletion renders the TRPM1 channel in retina inactive. J Neurophysiol 107:948-957. CrossRef Medline

Xu Y, Orlandi C, Cao Y, Yang S, Choi CI, Pagadala V, Birnbaumer L, Martemyanov KA, Vardi N (2016) The TRPM1 channel in ON-bipolar cells is gated by both the $\alpha$ and the $\beta \gamma$ subunits of the G-protein $\mathrm{G}_{\mathrm{o}}$. Sci Rep 6:20940. CrossRef Medline 